\title{
Thiazolidine Derivatives Attenuate Carrageenan-Induced Inflammatory Pain in Mice
}

This article was published in the following Dove Press journal:

Drug Design, Development and Therapy

\author{
Zulkifal Malik (1D ${ }^{1,2}$ \\ Muzaffar Abbas $\mathbb{D}^{2}$ \\ Lina Tariq Al Kury $\mathbb{D D}^{3}$ \\ Fawad Ali Shah (D) \\ Mahboob Alam ${ }^{2}$ \\ Arif-ullah Khan' \\ Humaira Nadeem' \\ Saad Alghamdi (iD) ${ }^{4}$ \\ Muhammad Umar Khayam \\ Sahibzada (iD $)^{5}$ \\ Shupeng $\mathrm{Li}^{6}$ \\ 'Riphah Institute of Pharmaceutical \\ Sciences, Riphah International University, \\ Islamabad, Pakistan; ${ }^{2}$ Faculty of Pharmacy, \\ Capital University of Science and \\ Technology, Islamabad, Pakistan; ${ }^{3}$ College \\ of Natural and Health Sciences, Zayed \\ University, Abu Dhabi, United Arab \\ Emirates; ${ }^{4}$ Laboratory Medicine \\ Department, Faculty of Applied Medical \\ Sciences, Umm Al-Qura University, \\ Mecca, Saudi Arabia; ${ }^{5}$ Department of \\ Pharmacy, Sarhad University of Science \\ and Information Technology, Peshawar, \\ KPK, Pakistan; ${ }^{6}$ State Key Laboratory of \\ Oncogenomics, School of Chemical \\ Biology and Biotechnology, Shenzhen \\ Graduate School, Peking University, \\ Shenzhen, People's Republic of China
}

Correspondence: Muzaffar Abbas Faculty of Pharmacy, Capital University of Science and Technology, Islamabad Expressway, Kahuta Road, Zone-V, Islamabad, Pakistan

Tel +92-5I-I I I 555666

Fax +92-5I-4486705

Email Muzaffar.abbas@cust.edu.pk

Shupeng Li

State Key Laboratory of Oncogenomics,

School of Chemical Biology and

Biotechnology, Shenzhen Graduate

School, Shenzhen, 5I8055, People's

Republic of China

Email lisp@pku.edu.cn
Background: Peripheral inflammation leads to the development of persistent thermal hyperalgesia and mechanical allodynia associated with increased expression of interleukin$1 \beta$ (IL-1 $\beta$ ) in the spinal cord. The aim of the present study was to investigate the effects of thiazolidine derivatives, $1 \mathrm{~b}$ ([2-(2-hydroxyphenyl)-1,3-thiazolidin-4-yl](morpholin-4-yl) methanone) and 1d (2-hydroxy-4-\{[2-(2-hydroxyphenyl)-1,3-thiazolidine-4-carbonyl $]$ amino benzoic acid), on thermal hyperalgesia, mechanical allodynia and on IL- $1 \beta$ expression during carrageenan-induced inflammation in the spinal cord in mice. Inflammatory pain was induced by injecting $1 \%$ carrageenan into the right hind paw of the mice.

Methods: The animals were administered thiazolidine derivatives, $1 \mathrm{~b}$ and $1 \mathrm{~d}(1 \mathrm{mg} / \mathrm{kg}, 3$ $\mathrm{mg} / \mathrm{kg}$, or $10 \mathrm{mg} / \mathrm{kg}$ ), intraperitoneally 30 minutes before carrageenan administration. The animals' behavior was evaluated by measuring thermal hyperalgesia, mechanical allodynia, and motor coordination. The IL-1 $\beta$ expression was measured by enzyme-linked immunosorbent assay. Acute and sub-acute toxicity studies were conducted to evaluate the toxicity profile of compounds.

Results: Treatment with the thiazolidine derivative, $1 \mathrm{~b}$ and $1 \mathrm{~d}$, attenuated carrageenaninduced thermal hyperalgesia and mechanical allodynia at doses of $1 \mathrm{mg} / \mathrm{kg}, 3 \mathrm{mg} / \mathrm{kg}$, and $10 \mathrm{mg} / \mathrm{kg}$. No motor coordination deficits were observed in animals. The compounds also reduced IL- $1 \beta$ expression in the spinal cord of mice. Acute and sub-acute toxicity studies revealed that both compounds were safe.

Conclusion: The compounds exhibit promising activity against inflammatory pain due to their ability to produce anti-hyperalgesic and anti-allodynic effects and to inhibit IL-1 $\beta$ expression in the spinal cord.

Keywords: inflammatory pain, IL-1 $\beta$, thiazolidine derivatives, mechanical allodynia, thermal hyperalgesia

\section{Introduction}

Pain is an essential adaptive response for the protection of the integrity of organism and arises in response to actual or potential tissue-damaging stimuli. In some instances, the component of pain persists despite the resolution of the inflammatory injury state. ${ }^{1}$ Animal models with chronic inflammatory states have demonstrated persistent allodynia (enhanced sensitivity to normally innocuous stimuli) and hyperalgesia (increased sensitivity of painful stimuli). ${ }^{2}$ Similarly, a substantial percentage of human patients have also shown an inability to resolve their pain after the resolution of the injury. ${ }^{3,4}$ As pathology of pain is highly variable and remains largely unresolved by currently available therapeutics, therefore there is a need to explore novel targets for the pain control. Production and the release of 
proinflammatory cytokines in the spinal cord has been recognized as an important mechanism in the induction and maintenance of pathological pain states in the animal models of pain. ${ }^{5,6}$ Targeting pro-inflammatory products including IL-1 $\beta$ for the treatment of pain is becoming widely recognized but it is still in infancy regarding potential drug targets identification for pain.

Interleukin-1 $\beta$ (IL-1 $\beta$ ) a key pro-inflammatory cytokine is the principal species of the interleukin-1 (IL-1) family and is involved in the development, maintenance, and propagation of pain sensitivity. ${ }^{7}$ IL- $1 \beta$ can be released from microglia, neuronal cells or astrocytes in the central nervous system (CNS), and produces additional allogenic substances. $^{7,8}$ It is found that in inflammatory pain increased production of inflammatory mediators like IL$1 \beta$ occurs, which acts on nociceptive neurons and produce hyperalgesia. ${ }^{9,10}$ Inhibitors of mediators such as interleukin-1 $\beta$ (Il-1 $\beta$ ) have shown remarkable analgesic effects. Pain associated behaviors in a mouse model of neuropathy are reduced in response to neutralizing antibodies to IL-1 $\beta$ receptors. ${ }^{11,12}$ Furthermore, thiazolidine derivatives have been found to exhibit very prominent anti-inflammatory and anti-nociceptive activity. ${ }^{13}$

Thiazolidine is an important scaffold and has a wide range of promising biological activities. Thiazolidine derivatives have reported anti-inflammatory and anti-nociceptive activity. ${ }^{14}$ In a similar study, thiazolidine derivatives exhibited promising anti-inflammatory and anti-nociceptive activity related to their ability to inhibit IL-1 $\beta$ production. $^{15}$ Various studies have reported that IL-1 $\beta$ production in the spinal cord is also increased in chronic pain similar to the increased IL-1 $\beta$ production in inflammatory pain. ${ }^{16-18}$ However, in this study our emphasis will be mainly on inflammatory pain. Therefore, the present study was designed to evaluate possible beneficial effects of synthetic thiazolidine derivatives such as 1b, ([2-(2hydroxyphenyl)-1,3-thiazolidin-4-yl](morpholin-4-yl) methanone and 1d, (2-hydroxy-4-\{[2-(2-hydroxyphenyl)1,3-thiazolidine-4-carbonyl] aminobenzoic acid), shown in Figures $1 \mathrm{~A}$ and B against carrageenan-induced hyperalgesia to thermal stimuli and mechanical allodynia. Usually, the endogenous antioxidant system keeps oxidative stress under control. However, oxidative stress increases during inflammatory processes at a rate which overcomes the capability of endogenous antioxidants to counter it. The resulting imbalance causes the oxidative stress productmediated injury and which results in the enhancement of pain. ${ }^{19,20}$ It has also been reported that there is a very
A

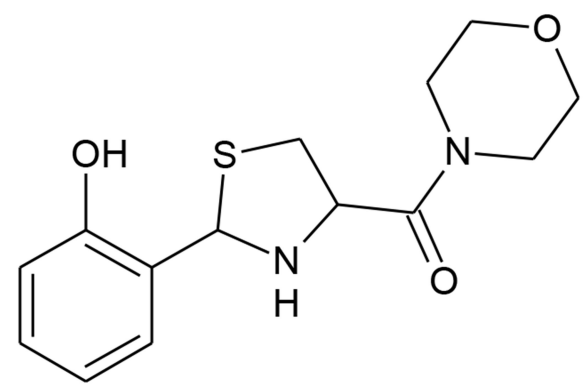

B

(1d)

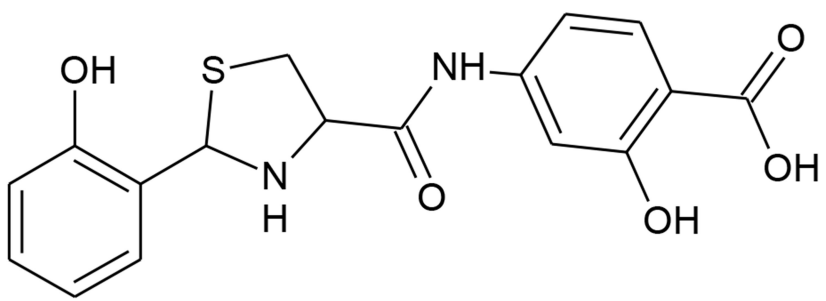

Figure I Structure of the thiazolidine derivatives; (A) (Ib) [2-(2-hydroxyphenyl)I,3-thiazolidin-4-yl](morpholin-4-yl)methanone, (B) (Id) 2-hydroxy-4-\{[2-(2-hydroxyphenyl)-1,3-thiazolidine-4-carbonyl]amino\}benzoic acid.

strong correlation between the oxidative stress and pain. ${ }^{21}$ The antioxidant potential of the thiazolidine compounds is also evaluated. We also investigated the effects of thiazolidine derivatives on IL- $1 \beta$ production in the spinal cord of an animal model. To evaluate the safety profile, acute and sub-acute toxicity studies of the compounds were also performed.

\section{Materials and Methods}

\section{Animals}

Adult male and female Balb-C mice weighing between 20-30 g were obtained from the animal house of Riphah Institute of Pharmaceutical Sciences (RIPS). Mice were divided into male and female groups $(n=6)$. Mice were housed four-to-five per cage in temperature and humiditycontrolled $\left(22^{\circ} \mathrm{C} \pm 2\right.$, the relative humidity of between 50 and $60 \%$ ) environment. A 12-hour of light and dark cycle was maintained and open access to water and food was provided to mice. Riphah Institute of Pharmaceutical Sciences Ethical Committee, Pakistan approved all the procedures prior to performing (Ref No. REC/RIPS/ 
2018/01). The guidelines of the Animals scientific procedures Act (1986) were followed which are in line with the guidelines of the Animal Welfare Act, 2009.

\section{Chemicals}

All the doses of the compounds were calculated based on the weight of the animals. The synthetic thiazolidine compounds, $1 \mathrm{~b}$, and $1 \mathrm{~d}$, were gifted by the laboratory of Pharmaceutical Chemistry Department, RIPS, Islamabad. Pakistan. 5\% Ethanol in saline was used as a vehicle for compound $1 \mathrm{~b}$ and $3 \%$ DMSO and $1.5 \%$ tween- 80 in saline was used as a vehicle for compound $1 \mathrm{~d}$. Rosiglitazone was obtained from Werrick pharmaceuticals through a proper channel and solution was prepared in normal saline. Diazepam was obtained from the market through the proper channel. Kappa-carrageenan was acquired from Sigma-Aldrich. Solution of carrageenan was prepared in normal saline.

\section{Induction of Inflammatory Pain and Drug Administration}

Acute inflammatory pain was induced by injecting $20 \mu \mathrm{L}$ of $1 \%$ carrageenan into the plantar surface of the right hind paw 30 minutes after intraperitoneal (IP) injection of thiazolidine derivatives. ${ }^{22-24}$ Control group animals were given vehicle $(10 \mathrm{~mL} / \mathrm{kg})$ only. Thirty minutes before the carrageenan injection each group of animals was given IP injections of $1 \mathrm{~b}$ or $1 \mathrm{~d}(1,3$, or $10 \mathrm{mg} / \mathrm{kg})$. Negative control group animals were given a same volume of vehicle $(5 \%$ ethanol in the case of $1 \mathrm{~b}$ and 3\% DMSO and 1.5\% Tween80 in the case of 1d). Positive control group animals received rosiglitazone 30 minutes before carrageenan injection. Behavioral assays (thermal hyperalgesia and mechanical allodynia) were carried out blindly before the injection of drug (naïve baseline), and then at intervals of every 30 minutes $(30,60,90,120,150$, minutes) after carrageenan injection. Each animal was tested three times for single recording with a 5 seconds interval between the two measurements to nullify the previous effect. ${ }^{22}$

\section{Thermal Hyperalgesia}

Increased sensitivity to thermal stimulus was measured by hot plate test maintained at $55^{\circ} \mathrm{C} \pm 2 .^{25,26}$ The animal were briefly positioned on the hot plate in a plexiglass chamber one by one. By using a stopwatch, paw withdrawal latency was measured. The licking of the paw, flicking, or jumping of the animal was noted as a positive response. A maximum of 30 seconds cut-off time was used to prevent tissue damage. ${ }^{27}$

\section{Measurement of Mechanical Allodynia}

Mechanical allodynia was measured according to the method described previously. ${ }^{28,29}$ Briefly, the mice after placement in a plexiglass cage with mesh metal flooring were acclimated to the environment for $30 \pm 5$ minutes Von Frey filaments of $0.16,0.4,0.6,1,1.4$, and $2 \mathrm{~g}$ were applied perpendicularly at the paw of mice using up and down method. Each filament was used with a force that caused slight bending and was held at same force for 2-3 seconds. The filament of $0.16 \mathrm{~g}$ was applied as a starting filament to the paw of the mice kept in mesh metal flooring. In the nonexistence of the withdrawal response of the paw to the initially selected lighter filament, a higher force filament matching to a stronger stimulus was applied. In the event of withdrawal response of paw, the next filament of lighter force was selected. The same procedure was repeated for consecutive five readings and the average value of five scores was calculated. ${ }^{30,31}$ A 2 g force was selected as cut-off force.

\section{Rota Rod Test}

To verify a possible effect of $1 \mathrm{~b}$ and $1 \mathrm{~d}$ on motor coordination in mice, a Rota Rod Test was used. ${ }^{32}$ The apparatus consisted of a horizontal bar with a diameter of $5 \mathrm{~cm}$, subdivided into four compartments. The mice were placed on the bar rotating at a speed of $4 \mathrm{rpm}$ and mice that were able to remain on the rod longer than 60 seconds were selected 24 hours before test. The animals were treated with two doses of $3 \mathrm{mg} / \mathrm{kg}$ and $10 \mathrm{mg} / \mathrm{kg}$ of compound $1 \mathrm{~b}$ and $1 \mathrm{~d}$, and vehicle $(10 \mathrm{~mL} / \mathrm{kg})$ or diazepam $(2.0 \mathrm{mg} / \mathrm{kg}$, IP). After 30 minutes following the administration of $1 \mathrm{~b}$ and $1 \mathrm{~d}$, each animal was tested on the rotarod and the time of permanence (s) on the bar during a 1 minute period was registered before ( 0 hour), 1 and 3 hours after drug administration.

\section{Enzyme-Linked Immunosorbent Assay (ELISA)}

IL- $1 \beta$ expression in the spinal cord of mice was measured by ELISA. ${ }^{13}$ At the end of the behavioral study experiment, the animals were sacrificed and their spinal cords were extracted. Until analysis, their spinal cord tissues were kept at $-80^{\circ} \mathrm{C}$. On the experiment day, tissues were homogenized in phosphate buffer saline (PBS) containing $5 \%$ tween-20 by probe sonicator. ${ }^{33}$ After homogenization 
the mixture was subjected to centrifugation at $8,500 \times \mathrm{g}$ for 30 minutes at $4^{\circ} \mathrm{C}$. After centrifugation, supernatants were collected. The mouse ELISA kit (E-EL-M0037) for IL-1 $\beta$ was employed to quantify IL- $1 \beta$ as per instructions provided by manufacturer.

\section{Antioxidant Activity by DPPH Radical Scavenging Assay}

Serial dilutions of compound $1 \mathrm{~b}$ were prepared having concentration of $1,3,10,100,300,700$, and 1,000 $\mu \mathrm{g} /$ $\mathrm{mL}$ in $5 \%$ ethanol. Similarly, serial dilutions of $1 \mathrm{~d}$ were prepared with a concentration of 1, 3, 10, 100, 700, and $1000 \mu \mathrm{g} / \mathrm{mL}$ in $3 \%$ DMSO and $1.5 \%$ Tween-80. Then 3 $\mathrm{mL}$ of freshly prepared $1 \mathrm{mM}$ DPPH prepared in methanol was added to each of the concentrations of tested compounds. After shaking, to complete the reaction, the mixture was allowed to stand in the dark for 30 minutes. A UV spectrophotometer was used to measure the absorbance of the solution at $517 \mathrm{~nm}$. The percentage of sample to inhibit DPPH was calculated by the following formula.

$$
\% \text { Inhibition }=\left\{\frac{A B S \text { control }- \text { ABS sample }}{A B S \text { control }}\right\} \% 100
$$

A concentration $(\mu \mathrm{M})$ against \% inhibition of DPPH graph was constructed. The concentration at which there was a $50 \%$ fall in the absorbance of DPPH solution was calculated from the graph $\left(\mathrm{IC}_{50}\right)$. All the experiments were performed in triplicate. For negative control the same experiment was performed without test compounds. Ascorbic acid was used as a standard (Positive control). ${ }^{34,35}$

\section{Determination of Acute and Sub-Acute Toxicity in the Animal Model}

For acute toxicity, male and female mice $(\mathrm{n}=3$ each) were divided into three groups. Group 1 received vehicle, group 2 received $1 \mathrm{~b}(1,000 \mathrm{mg} / \mathrm{kg})$, whereas group 3 received $1 \mathrm{~d}$ $(1,000 \mathrm{mg} / \mathrm{kg})$. The animals were then observed for the next 24 hours for their behavior and mortality. ${ }^{36,37}$ For sub-acute toxicity male and female mice ( $n=3$ each) were divided into three groups. Group 1 received IP dose of vehicles after every 24 hours for consecutive 14 days. ${ }^{38}$ Groups 2 and 3 were administered $500 \mathrm{mg}$ of $1 \mathrm{~b}$ and $1 \mathrm{~d}$ intraperitoneally every 24 hours for consecutive 14 days. Blood samples were withdrawn first after 24 hours of first dose of the compounds and then at the 14th day of administration of compounds. The blood was collected into non- heparinized tubes and centrifuged at 3,000 rpm for 10 minutes. The serum was separated and stored for biochemical analysis. Serum biochemical analysis was performed for alkaline-phosphatase (ALP), aspartate-aminotransferase (AST), alanine-aminotransferase (ALT), and creatinine. $^{39}$

\section{Statistical Analysis}

The Graph Pad Prism 6.0 (Graph-Pad, San Diego, CA) was used to analyze the data. Behavioral data was examined by using two-way ANOVA (two-way analysis of variance) followed by Tukey's post hoc test. For biochemical data, one way-ANOVA followed by Tukey's post hoc test was applied. Data were demonstrated as mean $\pm \mathrm{SEM}$. Significant statistical differences were at $* P<0.05$; $* * P<0.01 ; * * * P<0.001$.

\section{Results}

\section{Effect of Thiazolidine Derivatives on Carrageenan-Induced Thermal Hyperalgesia in Male Mice}

Adult male mice ( $n=6 /$ each group) were given an intraplantar injection of carrageenan (1\%) and then tested for hyperalgesia at $30,60,90,120$, and at 150 minute intervals. After 30 minutes of carrageenan injection reduction in mean withdraw latencies of paw in the negative control group was significant, $7 \pm 1.07 \mathrm{~s}$ $(* P<0.05)$ as compared to the saline given to the normal control group $(11.5 \pm 0.4 \mathrm{~s}, \mathrm{n}=6)$ (Figure $2 \mathrm{~A}$ and $\mathrm{B}$ ). Administration of the compound $1 \mathrm{~b}$ and $1 \mathrm{~d} 30$ minutes before the carrageenan injection was associated with significant increase in mean latency time on hot plate throughout different time intervals with all three doses (Figure 2A and B). However, the maximum increase in latency time $(P<0.001)$ in response to heat stimuli was observed with the dose $3 \mathrm{mg} / \mathrm{kg}$ and $10 \mathrm{mg} / \mathrm{kg}$ at 90 minutes interval $(19.83 \pm 2.2 \mathrm{~s} ; 18.33 \pm 1.6 \mathrm{~s})$ and 150 minutes interval $(14.50 \pm 1.3 \mathrm{~s} ; 14.33 \pm 0.3 \mathrm{~s})$ respectively (Figure 2A). Similarly, for compound 1d all three doses $(1,3$, and $10 \mathrm{mg} / \mathrm{kg}$ ) also reduced heat hypersensitivity response and increased the latency time on a hot plate significantly at 90 minutes interval $(17.83 \pm 2.9 \mathrm{~s} ; 17.16 \pm 0.4 \mathrm{~s}, 18.50 \pm 0.4 \mathrm{~s})$ and at 150 minutes interval $(15.16 \pm 1.6 \mathrm{~s} ; 16.66 \pm 0.6 \mathrm{~s} ; 19.16 \pm 0.9$ s) (Figure 2B). Finally intraperitoneal injection of rosiglitazone $(3 \mathrm{mg} / \mathrm{kg})$ increased the latency time of paw on hot plate starting from $12 \pm 1.12 \mathrm{~s}\left({ }^{*} P<0.05\right)$ at 60 


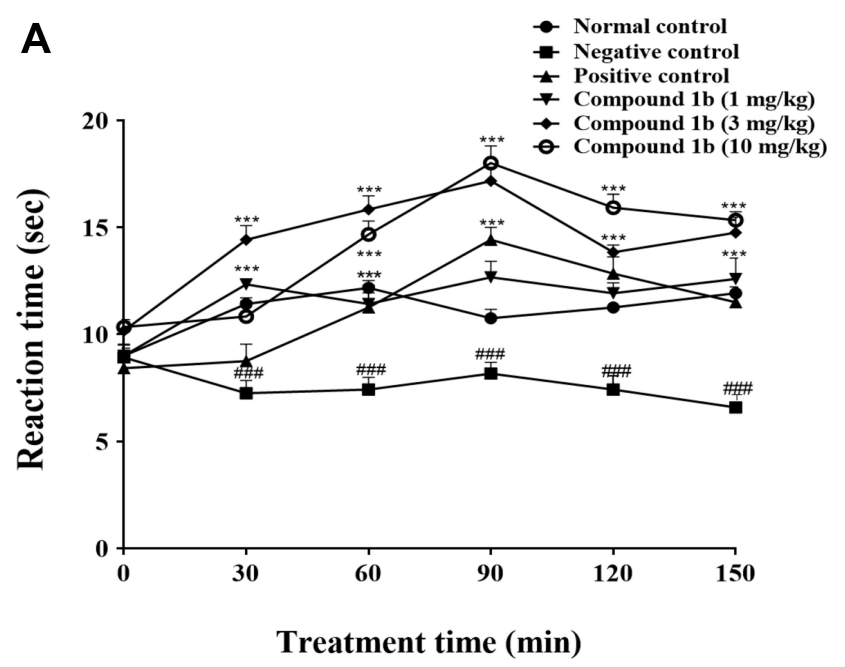

B

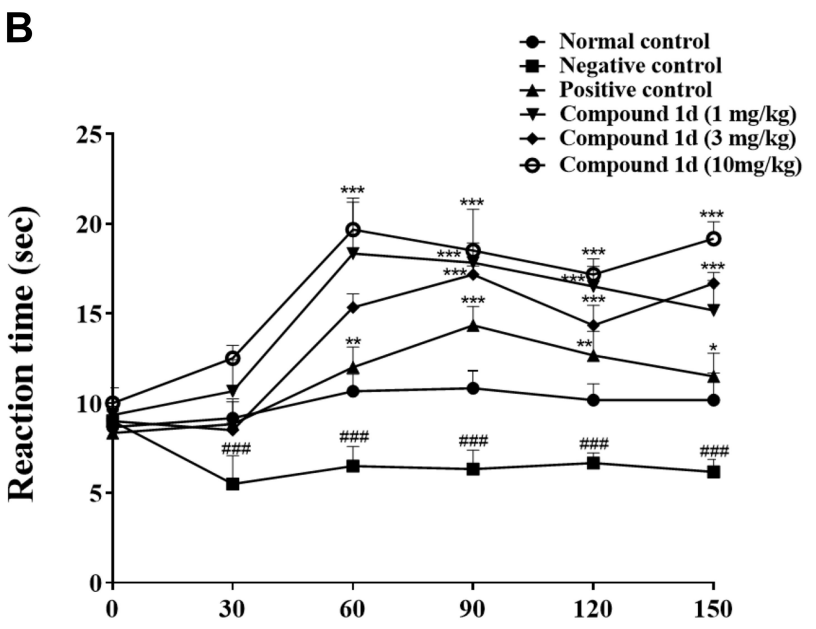

Treatment time (min)

Figure 2 Effects of thiazolidine derivatives on carrageenan-induced thermal hyperalgesia. Adult male mice ( $\mathrm{n}=6$ each group) received intra-plantar injection of carrageenan 30 minutes after an intraperitoneal dose of saline, vehicle $(5 \%$ ethanol, negative control in case of compound $\mathrm{Ib}$ ) and (3\% DMSO and I.5\% tween- 80 negative control in case of compound Id), rosiglitazone (3 mg/kg) as positive control; (A) Ib (I, 3, $10 \mathrm{mg} / \mathrm{kg})$ or (B) Id $(\mathrm{I}, 3,10 \mathrm{mg} / \mathrm{kg})$. Thermal pain sensitivity was measured prior to drug administration (naive baseline), and at 30,60,90,120, and at 150 minute interval after carrageenan injection by using hotplate assay $\left(54^{\circ} \mathrm{C} \pm 1\right)$. Results were analyzed by two-way ANOVA followed by Tukey's post hoc test. Data are expressed as mean \pm SEM. ${ }^{*} P<0.05$, ${ }^{* *} P<0.01$, $* * * P<0.001$. Denotes comparison between normal control vs negative control.

minutes, $14.33 \pm 1.05 \mathrm{~s}(* * * P<0.001)$ at 90 minutes, $12.66 \pm 1.33 \mathrm{~s}(* P<0.05)$ after 120 minutse and 11.50 $\pm 1.28 \mathrm{~s}(* P<0.05)$ after 150 minutes, relative to the negative control group $(\mathrm{n}=6)$ (Figure 2A and $\mathrm{B})$. When tested alone, compound $1 \mathrm{~b}$ and $1 \mathrm{~d}(1,3$, or $10 \mathrm{mg} / \mathrm{kg})$ increased latency time on hot plate compared to the normal control but not to significant extent indicating $1 \mathrm{~b}$ and $1 \mathrm{~d}$ possess mild-to-moderate analgesic potential as well (data not shown).

\section{Effect of Thiazolidine Derivatives on Carrageenan-Induced Thermal Hyperalgesia in Female Mice}

Adult female mice (n 6/each group) were given an intraplantar injection of carrageenan (1\%) and then tested for hyperalgesia at 30,60, 90, 120, and 150 minutes interval. Reduction in mean withdrawal latencies of the paw in the negative control group was significant as compared to the normal control group (Figure 3A and B). Administration of the compound $1 \mathrm{~b}$ and $1 \mathrm{~d} 30$ minutes before the carrageenan injection was associated with a significant increase in mean latency time on hot plate throughout different time intervals with all three doses (Figure $3 \mathrm{~A}$ and $\mathrm{B}$ ). However, the maximum increase in latency time $(P<0.001)$ in response to heat stimuli was observed with the dose $3 \mathrm{mg} / \mathrm{kg}$ and $10 \mathrm{mg} / \mathrm{kg}$ at 90 minutes interval $(17.0 \pm 0.73 \mathrm{~s} ; 19.33 \pm 0.61 \mathrm{~s})$ and 150 minutes interval $(15.83 \pm 0.9 \mathrm{~s} ; 17.43 \pm 0.82 \mathrm{~s})$, respectively (Figure 3A). Similarly, compound $1 \mathrm{~d} 3 \mathrm{mg} / \mathrm{kg}$ and $10 \mathrm{mg} / \mathrm{kg}$ doses also reduced heat hypersensitivity response and increased the latency time on hot plate significantly at 90 minutes interval $(14.83 \pm 0.41 \mathrm{~s}, 16.0 \pm 0.89 \mathrm{~s})$ and at 150 minutes interval (14.16 $\pm 0.47 \mathrm{~s} ; 16.66 \pm 0.42 \mathrm{~s})$ (Figure $3 \mathrm{~B})$. Finally intraperitoneal injection of rosiglitazone $(3 \mathrm{mg} / \mathrm{kg})$ increased the latency time of paw on hot plate starting at 60 minute $(* * P<0.01)$, at 90 minute $(* * * P<0.001)$, after 120 minute $(* * * P<0.001)$ and after 150 minute $(* * P<0.01)$, relative to the negative control group $(n=6)$ (Figure $3 \mathrm{~A}$ and $\mathrm{B})$. When tested alone, compound $1 \mathrm{~b}$ and $1 \mathrm{~d}(1,3$, or $10 \mathrm{mg} / \mathrm{kg}$ ) increased latency time on hot plate compared to normal control but not to significant extent indicating $1 \mathrm{~b}$ and $1 \mathrm{~d}$ possess mild-to-moderate analgesic potential as well (data not shown).

\section{Effect of Thiazolidine Derivatives on Carrageenan-Induced Mechanical Allodynia in Male Mice}

Carrageenan injection into the paw causes an increased sensitivity to tactile stimuli. The reduction was substantial in negative control (5\% Ethanol for 1b) starting from 30 minutes of intra-plantar injection of carrageenan at 0.250 $\pm 0.034 \mathrm{~g}(* P<0.05)$ and $0.267 \pm 0.021 \mathrm{~g}(* P<0.05)$ at 150 minute interval, in comparison to the saline group $(n=6)$ (Table 1A). Compound $1 \mathrm{~b}$ and $1 \mathrm{~d}$ produced anti-allodynic effects dose dependently. The anti-allodynic effects of compound $1 \mathrm{~b} 3 \mathrm{mg} / \mathrm{kg}$ were more prominent at 90 minute, $0.517 \pm 0.054 \mathrm{~g}(* * * P<0.001)$ and then were reduced at 150 


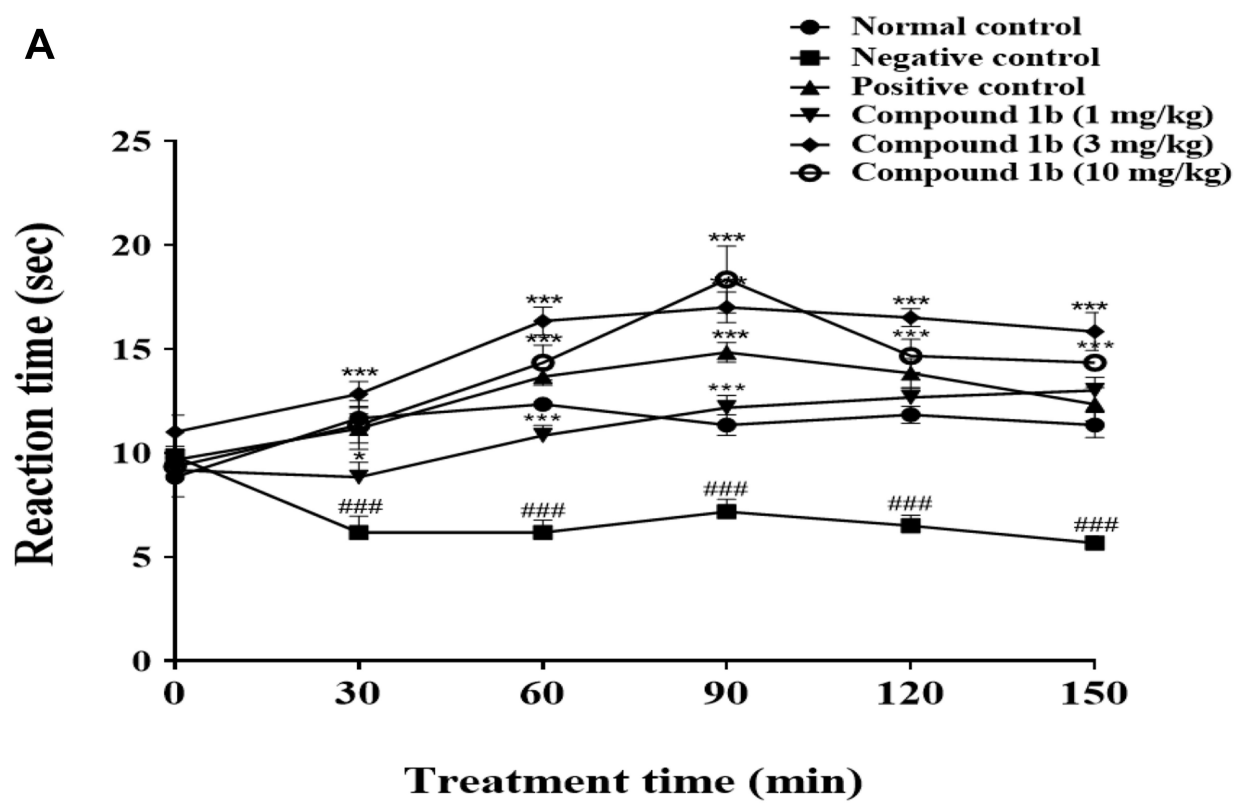

B

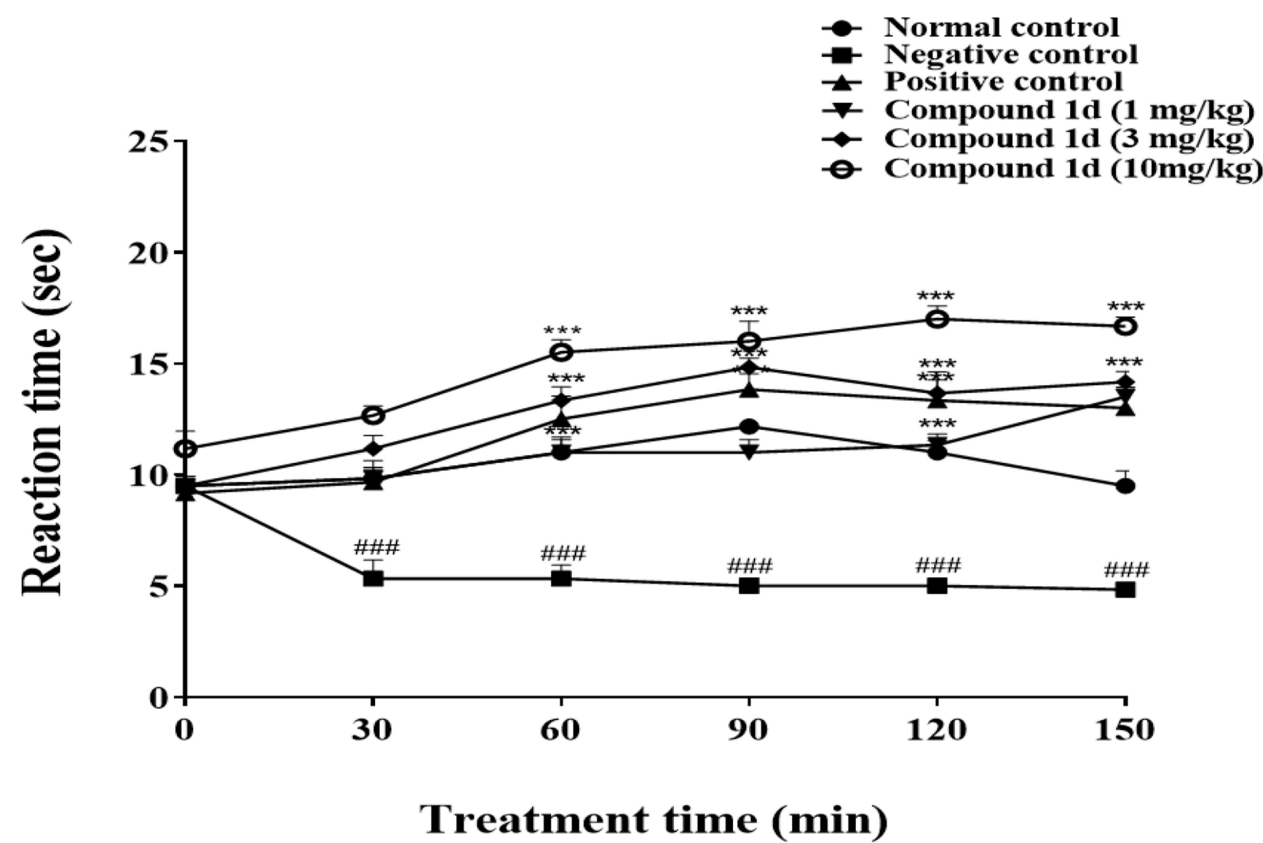

Figure 3 Effects of thiazolidine derivatives on carrageenan-induced thermal hyperalgesia. Adult female mice ( $\mathrm{n}=6$ each group) received intra-plantar injection of carrageenan after 30 minutes of intraperitoneal dose of saline, vehicle (5\% ethanol, negative control in case of compound Ib and $3 \%$ DMSO and I.5\% tween-80 negative control in case of compound Id), rosiglitazone ( $3 \mathrm{mg} / \mathrm{kg}$ ) as positive control; (A) Ib (I, 3, $10 \mathrm{mg} / \mathrm{kg})$ or (B) Id (I, 3, $10 \mathrm{mg} / \mathrm{kg})$. Thermal pain sensitivity was measured prior to drug administration (naive baseline), and at $30,60,90,120$, and at 150 minute interval after carrageenan injection by using hotplate assay $\left(54^{\circ} \mathrm{C} \pm \mathrm{I}\right.$ ). Results were analyzed by twoway ANOVA followed by Tukey's post hoc test. Data are expressed as mean \pm SEM. ${ }^{* * * P<0.001}$. Normal control vs negative control.

minute, $0.483 \pm 0.031 \mathrm{~g}\left({ }^{*} p P<0.05\right)$ relative to the negative control group (two-way ANOVA, n=6) (Table 1A). The higher dose of $1 \mathrm{~b} 10 \mathrm{mg} / \mathrm{kg}$ significantly reduced tactile allodynia at 90 minutes, $0.533 \pm 0.076 \mathrm{~g}(* * * P<0.001)$ and maintained up to 150 minutes, $0.650 \pm 0.022 \mathrm{~g}$ $(* * * P<0.001)$ relative to the negative control group (two- way ANOVA, $n=6$ ) (Table 1A). Similarly, compound 1d 3 $\mathrm{mg} / \mathrm{kg}$ reduced tactile allodynia significantly at $120 \mathrm{~min}-$ ute, $0.500 \pm 0.045 \mathrm{~g}(* * * P<0.001)$ and at 150 minute, 0.567 $\pm 0.033 \mathrm{~g}(* * * P<0.001)$ as compared to the negative control group (two-way ANOVA, $n=6$ ). The higher dose of $1 d$ $10 \mathrm{mg} / \mathrm{kg}$ produced the significant anti-allodynic effect at 
Table I Effect of Thiazolidine Derivatives on Carrageenan-Induced Mechanical Allodynia. Adult Male Mice ( $n=6$ Each Group), Received Intra-Plantar Injection of Carrageenan After 30 Minutes After Intraperitoneal Dose of Saline, Vehicle (5\% Ethanol, Negative Control in Case of Compound Ib) and (3\% DMSO and I.5\% Tween-80 Negative Control in Case of Compound Id), Rosiglitazone (3 mg/kg) as Positive Control; (A) Ib (I, 3, $10 \mathrm{mg} / \mathrm{kg}$ ) or (B) Id (I, 3, $10 \mathrm{mg} / \mathrm{kg}$ ). Mechanical Allodynia Was Measured Prior to Drug Administration (Nä̈ve Baseline), and at 30, 60, 90, I20, and at I 50 Minute Interval After Carrageenan Injection by Using Von Frey Filaments. Results Were Analyzed by Two-Way ANOVA Followed by Tuckey's Post Hoc Test. Data are Expressed as Mean \pm SEM.

\begin{tabular}{|c|c|c|c|c|c|c|c|c|}
\hline \multicolumn{9}{|l|}{ A } \\
\hline \multicolumn{9}{|c|}{ Mean Paw Withdrawal Latency (Mechanical Allodynia) } \\
\hline Time Duration (minutes) & Normal Control & Negative Control & Positive Control & $\begin{array}{l}\text { Compound lb } \\
(1 \mathrm{mg} / \mathrm{kg})\end{array}$ & \multicolumn{2}{|c|}{$\begin{array}{l}\text { Compound lb } \\
\text { ( } 3 \mathrm{mg} / \mathrm{kg} \text { ) }\end{array}$} & \multicolumn{2}{|c|}{$\begin{array}{l}\text { Compound lb } \\
(10 \mathrm{mg} / \mathrm{kg})\end{array}$} \\
\hline Zero time & $1.920 \pm 0.03$ & $1.96 \pm 0.040$ & $1.90 \pm 0.10$ & $1.960 \pm 0.04$ & \multicolumn{2}{|l|}{$2 \pm 0.01$} & \multicolumn{2}{|c|}{$1.880 \pm 0.05$} \\
\hline 30 & $1.307 \pm 0.09$ & $0.25^{\#} \pm 0.03$ & $0.517^{*} \pm 0.05$ & $0.383 \pm 0.04$ & \multicolumn{2}{|c|}{$0.433 \pm 0.07$} & \multicolumn{2}{|c|}{$0.483^{* * *} \pm 0.07$} \\
\hline 60 & $1.170 \pm 0.17$ & $0.33^{\#} \pm 0.06$ & $0.517 \pm 0.05$ & $0.403 \pm 0.07$ & \multicolumn{2}{|c|}{$0.550 * \pm 0.06$} & \multicolumn{2}{|c|}{$0.483^{*} \pm 0.03$} \\
\hline 90 & $1.263 \pm 0.11$ & $0.21^{\#} \pm 0.01$ & $0.583 * * * \pm 0.06$ & $0.417 * \pm 0.04$ & \multicolumn{2}{|c|}{$0.517 * * * \pm 0.05$} & \multicolumn{2}{|c|}{$0.533 * * 0.07$} \\
\hline 120 & $1.440 \pm 0.18$ & $0.21^{\#} \pm 0.01$ & $0.583 * * * \pm 0.04$ & $0.467^{*} \pm 0.04$ & \multicolumn{2}{|c|}{$0.450 * * \pm 0.05$} & \multicolumn{2}{|c|}{$0.617^{* * * *} \pm 0.04$} \\
\hline 150 & $1.560 \pm 0.14$ & $0.26^{\#} \pm 0.02$ & $0.533 * * \pm 0.04$ & $0.50 * \pm 0.06$ & \multicolumn{2}{|c|}{$0.483 * \pm 0.03$} & \multicolumn{2}{|c|}{$0.650^{* * * * \pm 0.02}$} \\
\hline \multicolumn{9}{|l|}{ B } \\
\hline \multicolumn{9}{|c|}{ Mean Paw Withdrawal Latency (Mechanical Allodynia) } \\
\hline Time Duration (minutes) & Normal Control & Negative Control & Positive Control & $\begin{array}{l}\text { Compo } \\
(1 \mathrm{mg} / \mathrm{l}\end{array}$ & $\begin{array}{l}\text { und Id } \\
\mathrm{gg} \text { ) }\end{array}$ & $\begin{array}{l}\text { Comp } \\
(3 \mathrm{mg} /\end{array}$ & $\begin{array}{l}\text { und Id } \\
\mathrm{gg} \text { ) }\end{array}$ & $\begin{array}{l}\text { Compound Id } \\
(10 \mathrm{mg} / \mathrm{kg})\end{array}$ \\
\hline Zero time & $1.90 \pm 0.05$ & $1.960 \pm 0.04$ & $1.90 \pm 0.1$ & $1.960 \pm 0$ & & $1.960 \pm C$ & & $1.880 \pm 0.05$ \\
\hline 30 & $1.313 \pm 0.09$ & $0.250^{\#} \pm 0.02$ & $0.517 \pm 0.05$ & $0.317 \pm 0$ & & $0.483 \pm C$ & & $0.553 * * \pm 0.04$ \\
\hline 60 & $1.256 \pm 0.16$ & $0.333^{\#} \pm 0.04$ & $0.517 \pm 0.05$ & $0.383 \pm 0$ & & $0.450 \pm C$ & & $0.567 * \pm 0.04$ \\
\hline 90 & $1.297 \pm 0.11$ & $0.217^{\#} \pm 0.04$ & $0.583 * * * \pm 0.06$ & $0.367 * \pm$ & 0.03 & $0.433 * *$ & 0.06 & $0.650 * * * \pm 0.02$ \\
\hline 120 & $1.447 \pm 0.17$ & $0.207^{\#} \pm 0.03$ & $0.583 * * * \pm 0.04$ & $0.383 * \pm$ & 0.01 & $0.500 * *$ & \pm 0.04 & $0.567^{* * * * \pm 0.04}$ \\
\hline 150 & $1.600 \pm 0.12$ & $0.230^{\#} \pm 0.03$ & $0.533 * * * \pm 0.04$ & $0.433 * \pm$ & 0.03 & $0.567 * * *$ & \pm 0.03 & $0.660 * * * \pm 0.02$ \\
\hline
\end{tabular}

Notes: $* P<0.05, * * p<0.01, * * * P<0.001 .{ }^{*}$ Denotes Comparison Between Normal Control vs Negative Control.

90 minute, $0.650 \pm 0.022 \mathrm{~g}(* * * P<0.001)$, at 120 minute, $0.567 \pm 0.042 \mathrm{~g}(* * * P<0.001)$, and at 150 minute intervals, $0.650 \pm 0.022 \mathrm{~g}(* * * P<0.001)$ (Table 1B). Injection of rosiglitazone $(3 \mathrm{mg} / \mathrm{kg})$ shows a significant reduction in tactile allodynia with $0.583 \pm 0.060 \mathrm{~g}(* * * P<0.001)$ at 90 minute, and $0.533 \pm 0.042 \mathrm{~g}(* * * P P<0.001)$ at 150 minutes after carrageenan injection as compared to the negative control group $(n=6)$ (Table 1A and B). These data indicate that administration of thiazolidine derivatives in higher doses attenuated the development of allodynia produced due to carrageenan administration.

\section{Effect of Thiazolidine Derivatives on Carrageenan-Induced Mechanical Allodynia in Female Mice}

Carrageenan injection into the paw causes an increased sensitivity to tactile stimuli. The reduction was substantial in negative control (5\% ethanol for $1 \mathrm{~b})$ starting at 30 minutes $\left({ }^{*} P<0.05\right)$ of intra-plantar injection of carrageenan and gradually reduced until the 150 minute interval
$(* * * P<0.05)$, in comparison to the normal control group $(\mathrm{n}=6)$ (Table 2A). Compound $1 \mathrm{~b}$ and $1 \mathrm{~d}$ produced antiallodynic effects dose dependently. At $\mathrm{mg} / \mathrm{kg}$ compound $1 \mathrm{~b}$ showed significant anti-allodynic effects at all the intervals starting at 60 minute $(* * * P<0.001)$ up-to 150 minute $\left({ }^{* * *} P<0.001\right)$ relative to the negative control group (twoway ANOVA, $n=6$ ) (Table 2A). The higher dose of $1 \mathrm{~b} 10$ $\mathrm{mg} / \mathrm{kg}$ significantly reduced tactile allodynia at all the intervals starting from 90 minutes $(* * * P<0.001)$ and maintained up-to 150 minutes $(* * * P<0.001)$ relative to the negative control group (two-way ANOVA, $n=6$ ) (Table 2A). Similarly, compound $1 \mathrm{~d} 3 \mathrm{mg} / \mathrm{kg}$ reduced tactile allodynia significantly at 90 minutes (***P<0.001), at 120 minutes $(* * * P<0.001)$, and at 150 minutes $(* * * P<0.001)$ as compared to the negative control group (two-way ANOVA, $\mathrm{n}=6$ ) (Table 2B). The higher dose of $1 \mathrm{~d} 10 \mathrm{mg} / \mathrm{kg}$ produced the significant anti-allodynic effect at 90 minute $(* * * P<0.001)$, at 120 minute $(* * * P<0.001)$, and at 150 minute interval $(* * * P<0.001)$ (Table 2B) as compared to the negative control group. Injection of Rosiglitazone $(3 \mathrm{mg} / \mathrm{kg}$ ) shows a significant 
Table 2 Effect of Thiazolidine Derivatives on Carrageenan-Induced Mechanical Allodynia. Adult Female Mice ( $n=6$ Each Group) Received Intra-Plantar Injection of Carrageenan After 30 Minutes of Intraperitoneal Dose of Saline, Vehicle (5\% Ethanol, Negative Control in Case of Compound Ib and 3\% DMSO and I.5\% Tween-80 Negative Control in Case of Compound Id), Rosiglitazone (3 $\mathrm{mg} / \mathrm{kg}$ ) as Positive Control; (A) Ib (I, 3, $10 \mathrm{mg} / \mathrm{kg}$ ) or (B) Id (I, 3, $10 \mathrm{mg} / \mathrm{kg}$ ). Mechanical Allodynia Was Measured Prior to Drug Administration (Naïve Baseline), and at 30, 60, 90, 120, and at 150 Minute Intervals After Carrageenan Injection by Using Von Frey Filaments. Results Were Analyzed by Two-Way ANOVA Followed by Tukey's Post Hoc Test. Data are Expressed as Mean \pm SEM

\begin{tabular}{|c|c|c|c|c|c|c|}
\hline \multicolumn{7}{|l|}{ A } \\
\hline \multicolumn{7}{|c|}{ Mean Paw Withdrawal Latency (Mechanical Allodynia) } \\
\hline $\begin{array}{l}\text { Time Duration } \\
\text { (minutes) }\end{array}$ & $\begin{array}{l}\text { Normal } \\
\text { Control }\end{array}$ & $\begin{array}{l}\text { Negative } \\
\text { Control }\end{array}$ & $\begin{array}{l}\text { Positive } \\
\text { Control }\end{array}$ & $\begin{array}{l}\text { Compound Ib } \\
(1 \mathrm{mg} / \mathrm{kg})\end{array}$ & $\begin{array}{l}\text { Compound Ib } \\
(3 \mathrm{mg} / \mathrm{kg})\end{array}$ & $\begin{array}{l}\text { Compound Ib } \\
(10 \mathrm{mg} / \mathrm{kg})\end{array}$ \\
\hline Zero time & $1.880 \pm 0.04$ & $1.96 \pm 0.04$ & $1.80 \pm 0.1$ & $1.92 \pm 0.04$ & $1.92 \pm 0.04$ & $1.92 \pm 0.05$ \\
\hline 30 & $1.333 \pm 0.09$ & $0.28^{\#} \pm 0.03$ & $0.64 * * * \pm 0.09$ & $0.43 \pm 0.05$ & $0.53 \pm 0.04$ & $0.64^{* *} \pm 0.05$ \\
\hline 60 & $1.323 \pm 0.18$ & $0.36^{\#} \pm 0.06$ & $0.55 * \pm 0.04$ & $0.50 \pm 0.05$ & $0.58 * \pm 0.04$ & $0.56 \pm 0.03$ \\
\hline 90 & $1.303 \pm 0.11$ & $0.21^{\#} \pm 0.01$ & $0.68 * * * \pm 0.03$ & $0.4 I \pm 0.04$ & $0.53 * * \pm 0.03$ & $0.63 * * * \pm 0.06$ \\
\hline 120 & $1.493 \pm 0.16$ & $0.23^{\#} \pm 0.01$ & $0.61 * * * \pm 0.06$ & $0.56 * * \pm 0.08$ & $0.53^{* *} \pm 0.03$ & $0.63 * * * \pm 0.05$ \\
\hline 150 & $1.660 \pm 0.12$ & $0.23^{\#} \pm 0.02$ & $0.63 * * * \pm 0.06$ & $0.53 * \pm 0.05$ & $0.50 * * \pm 0.03$ & $0.68 * * * \pm 0.04$ \\
\hline \multicolumn{7}{|l|}{ B } \\
\hline \multicolumn{7}{|c|}{ Mean Paw Withdrawal Latency (Mechanical Allodynia) } \\
\hline $\begin{array}{l}\text { Time Duration } \\
\text { (minutes) }\end{array}$ & $\begin{array}{l}\text { Normal } \\
\text { Control }\end{array}$ & $\begin{array}{l}\text { Negative } \\
\text { Control }\end{array}$ & $\begin{array}{l}\text { Positive } \\
\text { Control }\end{array}$ & $\begin{array}{l}\text { Compound Id } \\
(1 \mathrm{mg} / \mathrm{kg})\end{array}$ & $\begin{array}{l}\text { Compound Id } \\
(3 \mathrm{mg} / \mathrm{kg})\end{array}$ & $\begin{array}{l}\text { Compound Id } \\
(10 \mathrm{mg} / \mathrm{kg})\end{array}$ \\
\hline Zero time & $1.880 \pm 0.05$ & $1.96 \pm 0.040$ & $1.92 \pm 0.5$ & $1.88 \pm 0.05$ & $1.96 \pm 0.04$ & $1.96 \pm 0.05$ \\
\hline 30 & $1.347 \pm 0.08$ & $0.35^{\#} \pm 0.02$ & $0.66 * * * \pm 0.09$ & $0.40 \pm 0.04$ & $0.55 * \pm 0.05$ & $0.58 * \pm 0.04$ \\
\hline 60 & $1.377 \pm 0.16$ & $0.38^{\#} \pm 0.04$ & $0.62 * \pm 0.07$ & $0.46 \pm 0.03$ & $0.56 \pm 0.06$ & $0.60 * \pm 0.02$ \\
\hline 90 & I. $.367 \pm 0.08$ & $0.26^{\#} \pm 0.02$ & $0.66 * * * \pm 0.03$ & $0.46 * \pm 0.04$ & $0.56^{* * \pm 0.04}$ & $0.73 * * * \pm 0.02$ \\
\hline 120 & $1.513 \pm 0.15$ & $0.20^{\#} \pm 0.03$ & $0.69 * * * \pm 0.05$ & $0.45^{* *} \pm 0.03$ & $0.6 * * * \pm 0.02$ & $0.77^{* * *} \pm 0.05$ \\
\hline 150 & $1.627 \pm 0.13$ & $0.23^{\#} \pm 0.03$ & $0.69 * * * \pm 0.04$ & $0.48 * * \pm 0.04$ & $0.65 * * * \pm 0.02$ & $0.79 * * * \pm 0.07$ \\
\hline
\end{tabular}

Notes: $* P<0.05, * * P<0.01, * * * P<0.001$. ${ }^{*}$ Denotes Comparison Between Normal Control vs Negative Control.

reduction in tactile allodynia at all intervals as compared to the negative control group $(n=6)$ (Table $2 A$ and $B$ ). These data indicate that anti-allodynic effects of thiazolidine derivatives were increased at higher doses.

\section{Effect of Thiazolidine Derivatives on Rota-Rod Test}

Administration of diazepam $(2 \mathrm{mg} / \mathrm{kg})$ affect the motor coordination in mice and significantly reduced the time of permeance on bar after 1 hour $(P<0.001)$ and 3 hours $(P<0.001)$ in this test. Whereas the administration of $3 \mathrm{mg} /$ $\mathrm{kg}$ and $10 \mathrm{mg} / \mathrm{kg}$ doses of compound $1 \mathrm{~b}$ did not affect the motor coordination in mice and no significant change in the time of permanence on bar was observed at 1 hour and 3 hours after the administration of compound as compared to control (Figure 4A). Similarly, the $3 \mathrm{mg} / \mathrm{kg}$ and $10 \mathrm{mg} / \mathrm{kg}$ dose of compound $1 \mathrm{~d}$ did not affect the motor coordination in mice and no change was observed in the time of permanence at 1 hour and at 3 hours after administration of $1 \mathrm{~d}$ as compared to control (Figure 4B). These data suggest that the compounds lack effect on locomotor activity.

\section{Effect of Thiazolidine Derivatives on IL-I $\beta$ Production in the Spinal Cord in Response to Carrageenan-Induced Inflammation in Male Mice}

Peripheral inflammation in the negative control group caused a significant increase in the production of IL- $1 \beta$ in the spinal cord of mice as compared to the normal control (Figure 5A and $\mathrm{B})$. Compound $1 \mathrm{~b}(10 \mathrm{mg} / \mathrm{kg})$ caused a significant reduction in IL-1 $\beta$ production $(* * P<0.01)$ compared to the mice treated in the negative control group (Figure 5A). Similarly, injection of $1 \mathrm{~d}(10 \mathrm{mg} / \mathrm{kg})$ also reduced IL-1 $\beta$ production significantly $(* * P<0.01)$ in comparison to negative control (Figure 5B). Rosiglitazone administration also caused a decrease in IL- $1 \beta$ production significantly $(* * P<0.01)$ in comparison to the negative control treatment group (Figure 5A and B). 

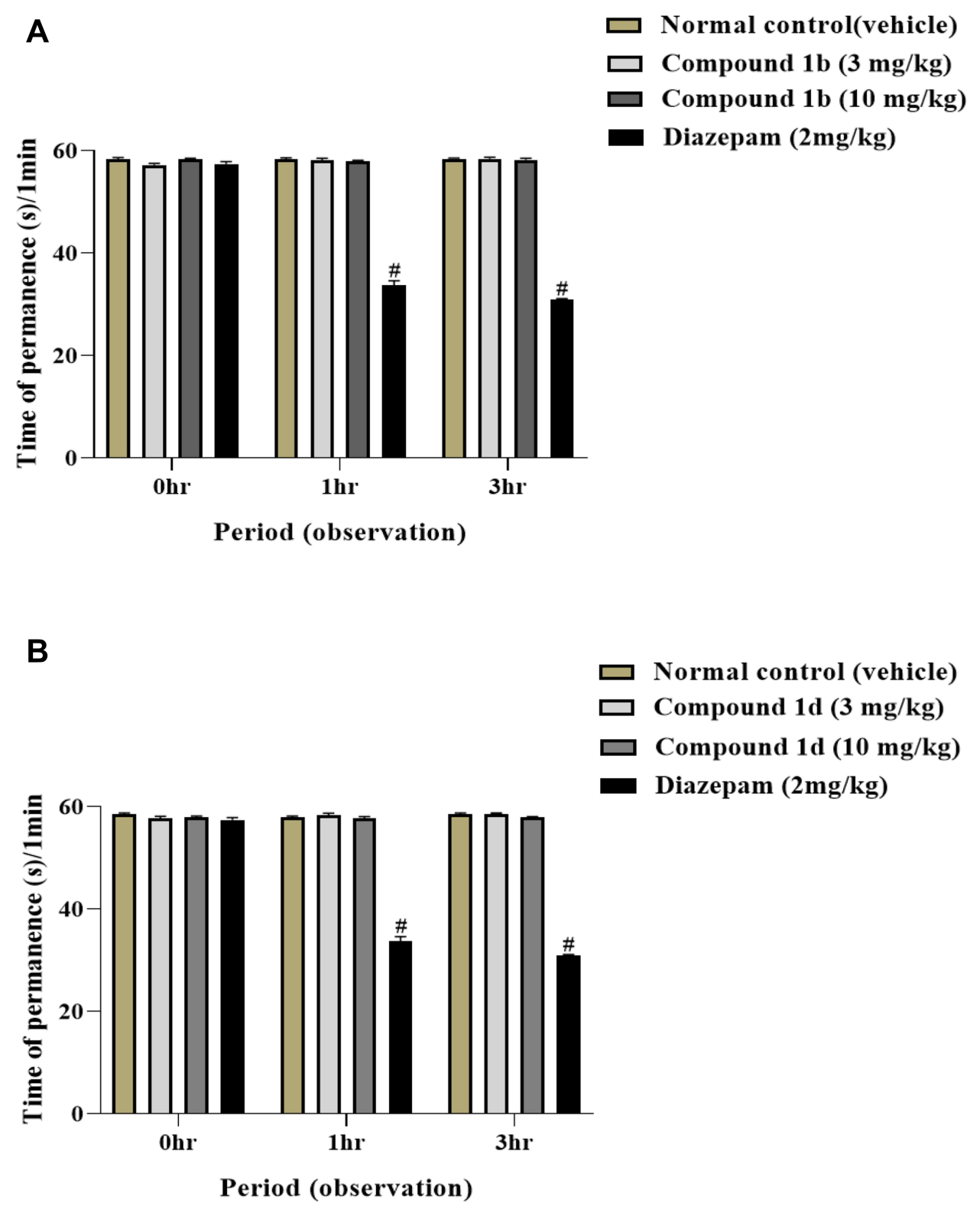

Figure 4 Effect of thiazolidine derivatives on time of permanence in Rota-rod test. Adult male mice ( $\mathrm{n}=6$ each group) received intraperitoneal injection of diazepam ( 2 mg/ $\mathrm{kg}$ ) dissolved in vehicle (5\% ethanol, in case of compound Ib and 3\% DMSO and I.5\% tween-80 in case of compound Id), (A) Compound Ib (3, I0 mg/kg) or (B) Compound Id $(3,10 \mathrm{mg} / \mathrm{kg})$. Time of permanence was measured prior to drug administration at 0 hour, and at I and 3 hours after drug administration by using Rota-Rod apparatus. Results were analyzed by two-way ANOVA followed by Tuckey's post-hoc test. Data are expressed as mean \pm SEM. ${ }^{\#}$ Normal control vs diazepam.

Effect of Thiazolidine Derivatives on IL-I $\beta$ Production in the Spinal Cord in

\section{Response to Carrageenan-Induced} Inflammation in Female Mice

Carrageenan and vehicle administered animal groups exhibited a significant increase in the production of IL-1 $\beta$ in the spinal cord of mice (Figure 6A and B). Compound $1 \mathrm{~b}(10 \mathrm{mg} / \mathrm{kg})$ caused a significant reduction in IL- $1 \beta$ production $(* * P<0.01)$ compared to the mice treated in the negative control group (Figure 6A). Similarly, the compound $1 \mathrm{~d}(10 \mathrm{mg} / \mathrm{kg})$ also reduced IL-1 $\beta$ production, $(* * P<0.01)$ in comparison to the negative control group (Figure 6B). Rosiglitazone administration also caused a significant decrease in the IL- $1 \beta$ production $(* * P<0.01)$ in comparison to the negative control treatment group (Figure 6A and B).

\section{Antioxidant Effect}

In the DPPH assay, the presence of free radicals decolorize DPPH, which is a stable free radical. Due to the change of color from purple to yellow the absorbance decreases as antioxidants scavenge the radical due to the donation of 


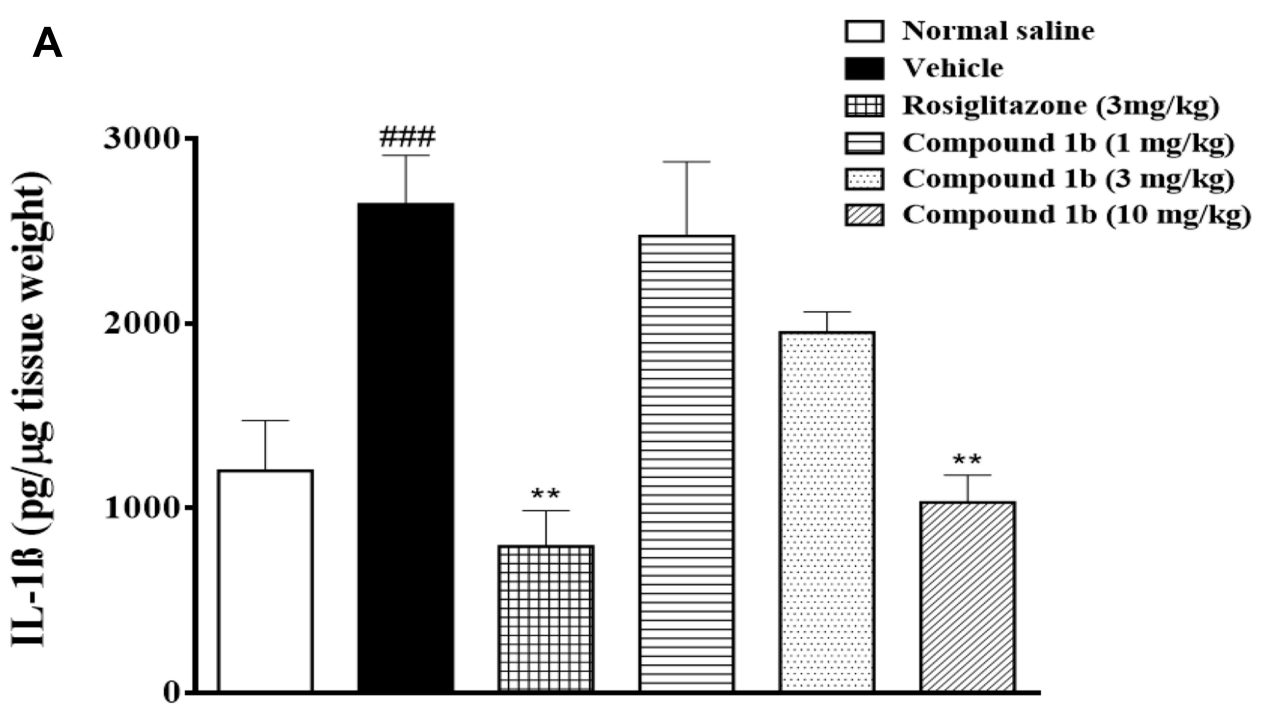

B

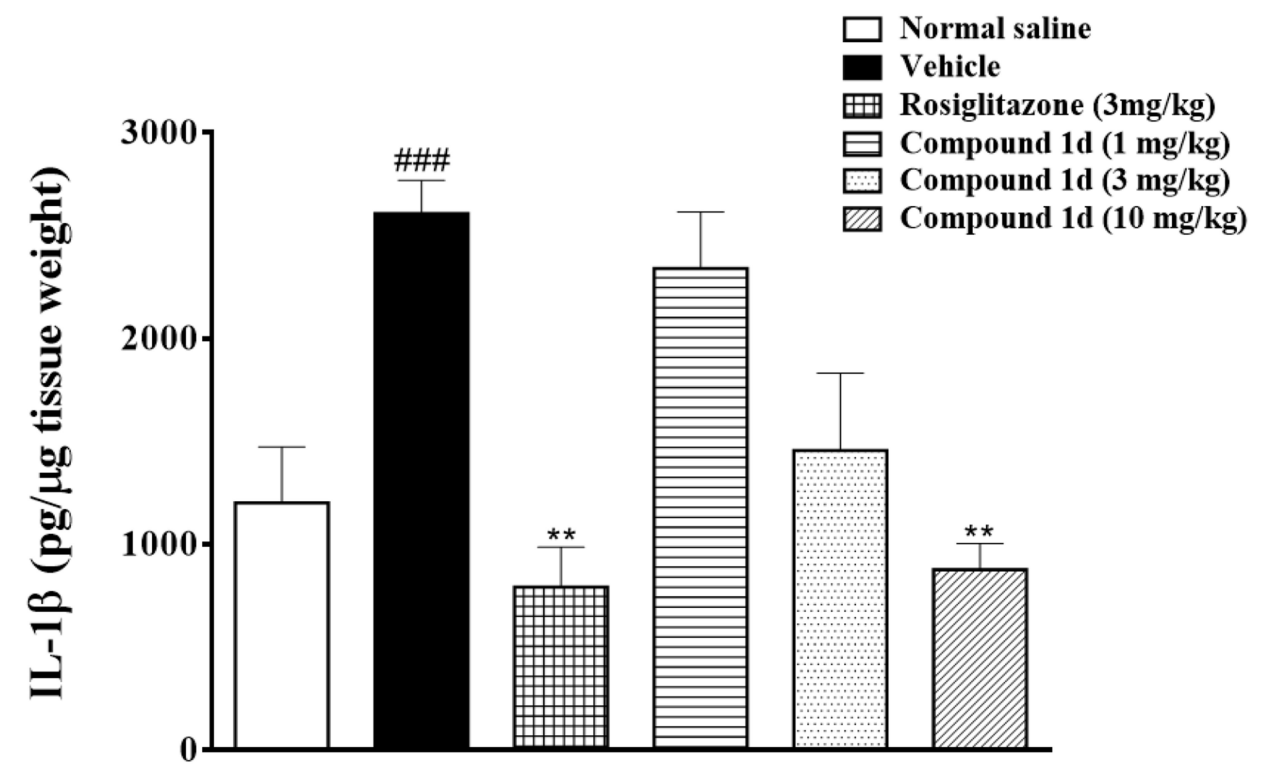

Figure 5 A. Effect of thiazolidine derivative, I bon IL-I $\beta$ production in the spinal cord in response to carrageenan-induced inflammation in male mice. B. Effect of thiazolidine derivative Id on IL-I $\beta$ production in the spinal cord in response to carrageenan-induced inflammation in male mice. Animals were sacrificed; spinal cords were isolated and stored at $-80^{\circ} \mathrm{C}$. The spinal cord was homogenized as described in the method section and the IL-I $\beta$ levels were measured by ELISA assay. $* * P<0.0 \mathrm{I}$. Analyzed by one-way ANOVA followed by Tukey's post hoc test. Normal control vs negative control.

hydrogen to make a stable DPPH-H molecule. Table 3 shows the free radical scavenging activity of the compound $1 \mathrm{~b}, 1 \mathrm{~d}$, and ascorbic acid. $\mathrm{IC}_{50}$ for each of the $1 \mathrm{~b}$, $1 \mathrm{~d}$, and ascorbic acid was calculated. $1 \mathrm{~b}$ with $\mathrm{IC}_{50}$ of 604 $\mu \mathrm{g} / \mathrm{mL}$ showed a radical scavenging effect. Similarly, the antioxidant activity of $1 \mathrm{~d}$ was observed with $\mathrm{IC}_{50}$ of 537 $\mu \mathrm{g} / \mathrm{mL}$. Meanwhile with the IC50 value of $244 \mu \mathrm{g} / \mathrm{mL}$ ascorbic acid exhibited the antioxidant activity. 

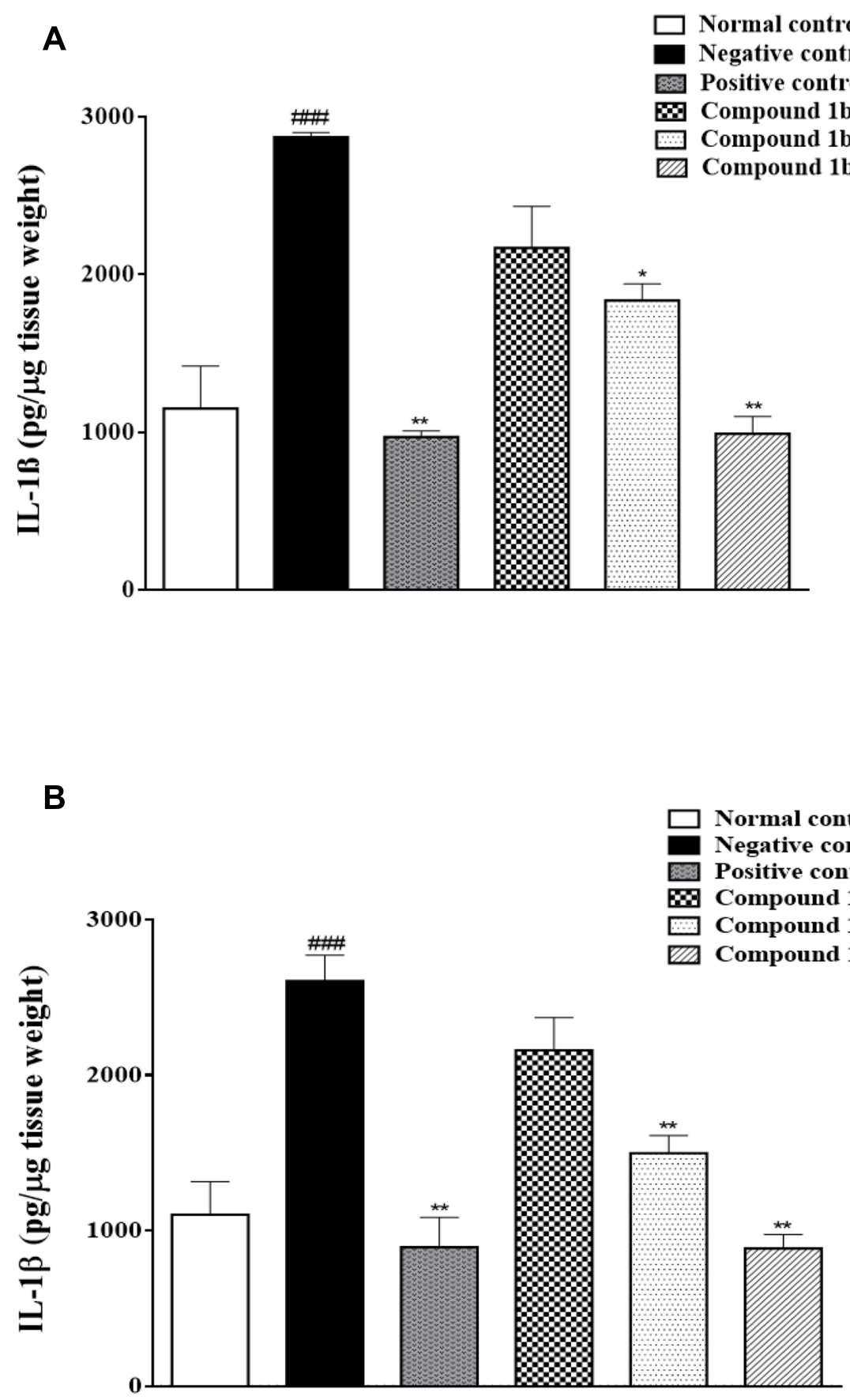

Figure 6 A. Effect of thiazolidine derivative, Ib, on IL-I $\beta$ production in the spinal cord in response to carrageenan-induced inflammation in female mice. B. Effect of thiazolidine derivative, Id on IL-I $\beta$ production in the spinal cord in response to carrageenan-induced inflammation in female mice.Animals were sacrificed; spinal cords were isolated and stored at $-80^{\circ} \mathrm{C}$. The spinal cord was homogenized as described in the method section and the IL-I $\beta$ levels were measured by ELISA assay. $* P<0.05$, $* * P<0.0 \mathrm{I}$. Analyzed by one-way ANOVA followed by Tukey's post hoc test. ${ }^{\text {Nomal }}$ control vs negative control.

\section{Acute and Sub-Acute Toxicity in Animal Model}

In acute toxicity study, all mice survived and no change in animal's behavior was observed after 24 hours of $1 \mathrm{~b}$ and $1 \mathrm{~d}$ administration. In sub-acute toxicity, to investigate the effects of thiazolidine derivatives on the liver injury, biomarkers of liver injury such as ALP, AST, and ALT were measured in the serum. The liver plays a major role in the metabolic processes of most substances. Thus, any disturbance in the liver could be reflected by the level of the biochemical parameters present in 
Table 3 Evaluation of the Antioxidant Activity by DPPH Method (Mean \pm SEM)

\begin{tabular}{|l|l|l|l|}
\hline Concentration $(\mu \mathrm{g} / \mathrm{mL})$ & Ib+DPPH & Id+DPPH & Ascorbic Acid \\
\hline $\mathrm{I}$ & $7.508672479 \pm 0.52$ & $4.434 \pm 0.16$ & $2.164 \pm 0.17$ \\
3 & $8.1765 \mathrm{I} 163 \pm 0.27$ & $19.939 \pm 0.22$ & $4.312 \pm 0.35$ \\
10 & $13.96236335 \pm 0.45$ & $38.034 \pm 0.08$ & $4.234 \pm 0.31$ \\
100 & $38.48731793 \pm 0.35$ & $38.704 \pm 0.53$ & $15.953 \pm 0.62$ \\
300 & $44.74783508 \pm 0.47$ & $41.941 \pm 0.02$ & $64.18 \mathrm{I} \pm 0.12$ \\
700 & $53.99150205 \pm 0.42$ & $56.963 \pm 0.24$ & $92.223 \pm 0.02$ \\
I000 & $57.19600295 \pm 0.99$ & $68.861 \pm 0.35$ & $93.290 \pm 0.07$ \\
Blank (negative control) & 3.199 & $2.77 \mathrm{I}$ & $3.34 \mathrm{I}$ \\
IC50 & $604 \mu \mathrm{g} / \mathrm{mL}$ & $537 \mu \mathrm{g} / \mathrm{mL}$ & $24 \mathrm{Ig} / \mathrm{mL}$ \\
\hline
\end{tabular}

the blood. During the damage to the liver cells and tissues, the activities of these enzymes are usually elevated. No significant change in the serum levels of liver injury biomarkers was observed after single day treatment and after 14 days of consecutive administration of the compounds (Table 4). Possible kidney damage with short-term administration (1 day) and long-term administration of the compounds was evaluated by measuring creatinine levels in the serum. No significant change in the creatinine level was observed after both shortterm and long-term administration of the compounds (Table 4).

\section{Discussion}

The current study reveals that administration of thiazolidine derivatives, $1 \mathrm{~b}$ and $1 \mathrm{~d}$, decreased carrageenaninduced thermal hyperalgesia and mechanical allodynia and reduced proinflammatory cytokines, IL-1 $\beta$ expression in both male and female mice groups. This indicates that thiazolidine derivatives reduce neuroinflammatory painlike symptoms involving decreased production of IL-1 $\beta$.

The subcutaneous injection of carrageenan produces local inflammation. The sensitivity to noxious stimuli (hyperalgesia) increases in peripheral tissue injury (inflammation) and also induces a sensation of pain in reaction to light-touch (allodynia). In the central nervous system enhanced responsiveness of nociceptive neurons to the normal afferent input is called central sensitization and it is considered a mechanism which is responsible for hyperalgesia and allodynia. ${ }^{40,41}$ Glial cells in the spinal dorsal horn are activated as a result of peripheral nerve injury and peripheral tissue injury. Activated glial cells in the spinal dorsal horn are involved in transmission of spinal nociception and central sensitization. ${ }^{42}$ Activated glial cells release multiple proinflammatory mediators in the spinal cord. $^{43}$ Pro-inflammatory mediators such as IL- $1 \beta$ rise in the spinal cord in response to nerve damage or peripheral inflammation. ${ }^{44}$ The excitability of primary neurons in response to external stimuli is increased by spinal proinflammatory mediators. ${ }^{40,45}$

Peroxisome proliferator-activated receptors act as ligandactivated transcription factors. These receptors belong to the nuclear hormone receptor superfamily. Three types of PPAR $\alpha, \beta$, and $\gamma$ have been identified. These receptors play a very important role in the production of immunomodulatory cytokines. ${ }^{46}$ Some previous studies have shown that PPAR $\gamma$

Table 4 Levels of the Liver and Kidney Injury Biomarkers Observed in Male and Female Mice After the Short-Term (I Day) and LongTerm (I4 Days) Administration of the Thiazolidine Derivates. The Values are Expressed as Mean \pm SD of Six Animals

\begin{tabular}{|c|c|c|c|c|c|c|c|c|c|}
\hline & & \multicolumn{4}{|l|}{ I Day } & \multicolumn{4}{|l|}{ I4 Days } \\
\hline & & ALP (U/L) & AST (U/L) & ALT (U/L) & Creatinine $(\mu \mathrm{mol} / \mathrm{L}$ & ALP (U/L) & AST (U/L) & ALT (U/L) & Creatinine $(\mu \mathrm{mol} / \mathrm{L})$ \\
\hline \multirow[t]{2}{*}{ Control } & Male & $10.67 \pm 1.20$ & $42.34 \pm 1.22$ & $|2.2| \pm 0.8$ & $17.64 \pm 0.54$ & $11.57 \pm 1.34$ & $46.15 \pm 1.11$ & $|3.8| \pm 1.24$ & $15.74 \pm 0.46$ \\
\hline & Female & $11.43 \pm 1.22$ & $50.5 \pm 1.44$ & $14.20 \pm 0.9$ & $16.12 \pm 0.81$ & $13.23 \pm 2.1$ & $54.6 \pm 0.74$ & $15.50 \pm 0.29$ & $\mid 7.32 \pm 1.31$ \\
\hline \multirow[t]{2}{*}{ Compound Ib } & Male & $10.43 \pm 1.22$ & $40.21 \pm 1.20$ & II. $.47 \pm 0.7$ & $17.23 \pm 0.77$ & $14.33 \pm 1.05$ & $53.13 \pm 1.35$ & $13.86 \pm 0.44$ & $19.36 \pm 1.42$ \\
\hline & Female & $13.21 \pm 1.22$ & $51.14 \pm 1.6$ & $12.63 \pm 1.4$ & $17.86 \pm 0.64$ & $|5.3| \pm 0.88$ & $55.64 \pm 1.33$ & $|3.88 \pm 0.4|$ & $19.42 \pm 1.67$ \\
\hline \multirow[t]{2}{*}{ Compound Id } & Male & $11.3 \pm 0.0 .99$ & $43.52 \pm 1.24$ & $12.5 \pm 0.8$ & $15.17 \pm 1.22$ & $13.45 \pm 0.1 .35$ & $54.11 \pm 2.23$ & $\mid 4.61 \pm 0.89$ & $20.42 \pm 1.0$ \\
\hline & Female & $12.5 \pm 0.88$ & $52.4 I \pm 2.2$ & $14.83 \pm 0.6$ & $16.82 \pm 1.06$ & $14.53 \pm 1.45$ & $54.75 \pm 1.12$ & $15.73 \pm 0.48$ & $19.71 \pm 1.5$ \\
\hline
\end{tabular}


ligands exert additional CNS actions on nociceptive signaling pathways, likely by their action at PPAR receptors in the brain. ${ }^{47}$ The involvement of PPAR $\gamma$ in inflammatory processes was first suggested by the antagonism between the activities of proinflammatory cytokines and PPAR $\gamma .{ }^{48}$ It was reported that mice deficient of PPAR $\gamma$ receptor had a greater inflammatory response which was induced by both arachidonic acid and leukotriene B4. PPAR $\gamma$ ligands also lessened the behavioral signs of inflammatory pain in rats which was confirmed by a study on PPAR- $\alpha$ deletion-mutant mice. ${ }^{49,50}$ In a study conducted, it was observed that repeated thiazolidine derivatives doses cause reduction of inflammatory pain via action on PPAR $\gamma$ receptors. ${ }^{51}$ Thiazolidine derivatives agonize PPAR $\gamma$ in the spinal cord and reduce inflammatory cytokines. $^{52-55}$

Thiazolidine derivatives, $1 \mathrm{~b}$, and $1 \mathrm{~d}$, are promising anti-inflammatory candidates and possess possible therapeutic potential for the management of inflammatory pain. In this study, the thiazolidine derivatives exerted pronounced anti-inflammatory effects by reducing the levels of proinflammatory cytokines such as IL-1 $\beta$. It was also suggested that thiazolidine derivatives might exert these effects of reducing levels of IL-1 $\beta$ by acting on PPARs. ${ }^{15}$ $1 \mathrm{~b}(3$ or $10 \mathrm{mg} / \mathrm{kg}$ ) increased the duration of reaction to the hot plate test. Compound $1 \mathrm{~b}$ also causes an increase in the withdrawal threshold of the mice paw at doses (3 or $10 \mathrm{mg} / \mathrm{kg}$ ) in Von Frey filament test. Similarly, the time of reaction to the hot plate was increased by $1 \mathrm{~d}(1,3$, or $10 \mathrm{mg} / \mathrm{kg}$ ) and a greater paw withdrawal threshold at a dose of $10 \mathrm{mg} / \mathrm{kg}$. All these results show that both compounds are more successful at higher doses in producing desired effects. It was also observed that the anti-nociceptive activity of these compounds could not be due to their sedative effect, because the results of the Rota-rod test did to exhibit any motor coordination defects in mice administered $1 \mathrm{~b}$ and $1 \mathrm{~d}$ which implies that compounds do not have any sedative or motor coordination effects. Thiazolidine derivatives $1 \mathrm{~b}$ or $1 \mathrm{~d}(1,3$, or $10 \mathrm{mg} / \mathrm{kg})$ dose-dependently reduced IL- $1 \beta$ production in the lumbar spinal cord of the mice in response to carrageenan-induced peripheral inflammation in exhibiting a reduction in proinflammatory cytokines contents. In a similar study, thiazolidine derivatives exhibited promising anti-inflammatory, antinociceptive activities which are related to their ability to inhibit IL-1 $\beta$ production. Inflammation is the veritable cause of pain, and inhibitors of inflammatory mediators like IL-1 $\beta$ have shown remarkable analgesic effects. However, when tested alone, compound $1 \mathrm{~b}$ and $1 \mathrm{~d}(1,3$, or $10 \mathrm{mg} / \mathrm{kg}$ ) increased latency time on hot plate compared to normal control but not to a significant extent, indicating $1 \mathrm{~b}$ and $1 \mathrm{~d}$, in addition to anti-hyperalgesic effect, possess mild-to-moderate analgesic potential (data not shown).

All these data taken together propose that thiazolidine derivatives $1 \mathrm{~b}$ and $1 \mathrm{~d}$ administration may reduce the neuroinflammatory consequence of inflammatory pain as it reduces the IL-1 $\beta$ up-regulation in the lumber spinal cord region of mice in which inflammatory pain was induced by carrageenan, which indicates that pro-inflammatory consequences of peripheral inflammation can be reduced by administration of thiazolidine derivatives.

A close relationship between oxidative stress and inflammation has been reported so that oxidative stress following inflammation can induce more inflammation through different pathways and vice versa. ${ }^{21,56,57}$ Previous studies have shown that cytokines alter the redox equilibrium by affecting GSH/GSSG shuttling and recycling. ${ }^{58,59}$ It has been observed that antioxidants effectively suppressed the expression of proinflammatory cytokines, such as IL-1 $\beta$ as well as oxidants induced by ischemia injury. ${ }^{60}$ It has been reported that IL-1 $\beta$ is an effective mediator of spinal cord inflammation and oxidative stress, and blocking IL- $1 \beta$ could be a potential therapy for pain hypersensitivity development. ${ }^{61}$ Studies have reported that reducing the levels of oxidative stress products in the spinal cord reduced hyperalgesia and allodynia. ${ }^{19,62-64}$ The in vitro antioxidant activities of the thiazolidine derivatives were also performed by DPPH free radical scavenging assay. Antioxidants have a hydrogen donating ability, hence provide DPPH free radical scavenging. The antioxidant potential of both compounds was promising on the basis of their calculated IC50 value.

The acute toxicity showed the safety of thiazolidine derivatives, as no mortality or other significant gross behavioral changes were observed at $1,000 \mathrm{mg} / \mathrm{kg}$. Therefore, LD50 of the compounds could be greater than 1,000 mg/ $\mathrm{kg}$. In a sub-acute toxicity study, no significant alleviation in the serum levels of liver injury biomarkers ALP, AST, and ALT were observed after 14 days of the treatment with thiazolidine derivatives $1 \mathrm{~b}$ and $1 \mathrm{~d}$. ALP is a known marker enzyme for plasma membrane and endoplasmic reticulum of the tissue. It is an indicator of acute liver damage. ALT has its highest concentration in the liver, with kidney and skeletal muscles having lesser activity of these enzymes. It is also an acute liver damage indicator. Creatinine levels in the serum after 14 days of the treatment with thiazolidine derivatives also did not change significantly, suggesting 
that thiazolidine derivatives $1 \mathrm{~b}$ and $1 \mathrm{~d}$ are not toxic to the kidney cells. Studies previously conducted on acute toxicity (LD50) of thiazolidine derivatives in a range of oral doses $25,50,100,250,500$, and $1,000 \mathrm{mg} / \mathrm{kg}$ did not show any toxicity. Similarly, in another study thiazolidine derivatives were shown to be safe according to the parameters of mutagenicity, teratogenicity, carcinogenicity, and reproductive toxicity. ${ }^{65}$

\section{Conclusion}

In conclusion, the present study clearly demonstrates that thiazolidine derivatives: [2-(2 hydroxyphenyl)-1,3-thiazolidin-4-yl](morpholin-4-yl)methanone, and 2-hydroxy-4-\{[2(2-hydroxyphenyl)-1,3-thiazolidine-4-carbonyl]amino\} benzoic acid exhibit analgesic effects with 1-d having pronounced activity than 1-b. Their possible mechanism is due to PPAR $\gamma$ agonist activity, which indicates their therapeutic potential in inflammatory pain. The analgesic effects and ability to suppress IL-1 $\beta$ expression in spinal cord increased with higher doses. However, it is suggested that further research on underlying pathways of inflammatory pain is required that would improve the clinical management of inflammatory pain.

\section{Acknowledgments}

We are thankful to Dr. Alam Zeb and Dr. Shafi Ullah for their valuable support in the editorial process.

\section{Disclosure}

The authors declare no conflicts of interest for this work.

\section{References}

1. Kehlet H, Jensen TS, Woolf CJ. Persistent postsurgical pain: risk factors and prevention. Lancet. 2006;367(9522):1618-1625. doi:10.1016/S0140-6736(06)68700-X

2. Christianson CA, Corr M, Firestein GS, Mobargha A, Yaksh TL, Svensson CI. Characterization of the acute and persistent pain state present in K/BxN serum transfer arthritis. Pain. 2010;151(2):394-403. doi:10.1016/j.pain.2010.07.030

3. Nathan JD, Pappas TN. Inguinal hernia: an old condition with new solutions. Ann Surg. 2003;238(6 Suppl):S148-157. doi:10.1097/01. sla.0000097796.63010.e8

4. Vadivelu N, Schreck M, Lopez J, Kodumudi G, Narayan D. Pain after mastectomy and breast reconstruction. Am Surg. 2008;74(4):285-296. doi: $10.1177 / 000313480807400402$

5. Fields RD. New culprits in chronic pain. Sci Am. 2009;301(5):50-57. doi:10.1038/scientificamerican1109-50

6. Watkins LR, Hutchinson MR, Ledeboer A, Wieseler-Frank J, Milligan ED, Maier SF. Glia as the "bad guys": implications for improving clinical pain control and the clinical utility of opioids. Brain Behav Immun. 2007;21(2):131-146. doi:10.1016/j.bbi.2006.10.011
7. Ren $\mathrm{K}$, Torres R. Role of interleukin-1 $\beta$ during pain and inflammation. Brain Res Rev. 2009;60(1):57-64. doi:10.1016/j. brainresrev.2008.12.020

8. Li Z-Y, Zhang Y-P, Zhang J, et al. The possible involvement of JNK activation in the spinal dorsal horn in bortezomib-induced allodynia: the role of TNF- $\alpha$ and IL-1 $\beta$. J Anesth. 2016;30(1):55-63. doi:10.1007/s00540-015-2077-x

9. Lu X, Zeng R, Lin J, et al. Pharmacological basis for use of madecassoside in gouty arthritis: anti-inflammatory, anti-hyperuricemic, and NLRP3 inhibition. Immunopharmacol Immunotoxicol. 2019;41 (2):277-284. doi:10.1080/08923973.2019.1590721

10. Matsuda M, Huh Y, Ji -R-R. Roles of inflammation, neurogenic inflammation, and neuroinflammation in pain. J Anesth. 2019;33 (1):131-139. doi:10.1007/s00540-018-2579-4

11. Johnston IN, Milligan ED, Wieseler-Frank J, et al. A role for proinflammatory cytokines and fractalkine in analgesia, tolerance, and subsequent pain facilitation induced by chronic intrathecal morphine. $J$ Neurosci. 2004;24(33):7353-7365. doi:10.1523/JNEUROSCI.18 50-04.2004

12. Pinho-Ribeiro FA, Zarpelon AC, Fattori V, et al. Naringenin reduces inflammatory pain in mice. Neuropharmacology. 2016;105:508-519. doi:10.1016/j.neuropharm.2016.02.019

13. Barros CD, Amato AA, de Oliveira TB, et al. Synthesis and antiinflammatory activity of new arylidene-thiazolidine-2, 4-diones as PPAR $\gamma$ ligands. Bioorg Med Chem. 2010;18(11):3805-3811. doi:10.1016/j.bmc.2010.04.045

14. Uchôa FDT, da Silva TG, de Lima M, Galdino SL, Pitta I, Costa TD, Preclinical pharmacokinetic and pharmacodynamic evaluation of thiazolidinone PG15: an anti-inflammatory candidate. $J$ Pharm Pharmacol. 2009;61(3):339-345. doi:10.1211/jpp.61.03.0008

15. Malta D, Araújo LCC, Carrazoni AS, et al. Anti-inflammatory, antiarthritic and antinociceptive activities of 3,5-disubstituted thiazolidine derivatives. Br J Pharm Res. 2014;4(8):992-1003. doi:10.9734/ BJPR/2014/8736

16. Hua XY, Svensson CI, Matsui T, Fitzsimmons B, Yaksh TL, Webb M. Intrathecal minocycline attenuates peripheral inflammationinduced hyperalgesia by inhibiting p38 MAPK in spinal microglia. Eur $J$ Neurosci. 2005;22(10):2431-2440. doi:10.1111/j.14609568.2005.04451.x

17. Ledeboer A, Sloane EM, Milligan ED, et al. Minocycline attenuates mechanical allodynia and proinflammatory cytokine expression in rat models of pain facilitation. Pain. 2005;115(1-2):71-83. doi:10.1016/ j.pain.2005.02.009

18. Tsuda M, Inoue K, Salter MW. Neuropathic pain and spinal microglia: a big problem from molecules in 'small'glia. Trends Neurosci. 2005;28(2):101-107. doi:10.1016/j.tins.2004.12.002

19. Khattab MM. TEMPOL, a membrane-permeable radical scavenger, attenuates peroxynitrite-and superoxide anion-enhanced carrageenaninduced paw edema and hyperalgesia: a key role for superoxide anion. Eur J Pharmacol. 2006;548(1-3):167-173. doi:10.1016/j. ejphar.2006.08.007

20. Valerio DA, Georgetti SR, Magro DA, et al. Quercetin reduces inflammatory pain: inhibition of oxidative stress and cytokine production. $J$ Nat Prod. 2009;72(11):1975-1979. doi:10.1021/np900259y

21. Little JW, Doyle T, Salvemini D. Reactive nitroxidative species and nociceptive processing: determining the roles for nitric oxide, superoxide, and peroxynitrite in pain. Amino Acids. 2012;42(1):75-94. doi:10.1007/s00726-010-0633-0

22. Bagdas D, AlSharari SD, Freitas K, Tracy M, Damaj MI. The role of alpha5 nicotinic acetylcholine receptors in mouse models of chronic inflammatory and neuropathic pain. Biochem Pharmacol. 2015;97 (4):590-600. doi:10.1016/j.bcp.2015.04.013

23. Freitas K, Ghosh S, Carroll FI, Lichtman AH, Damaj MI. Effects of alpha 7 positive allosteric modulators in murine inflammatory and chronic neuropathic pain models. Neuropharmacology. 2013;65:156164. doi:10.1016/j.neuropharm.2012.08.022 
24. McCarson KE. Models of inflammation: carrageenan-or complete freund's adjuvant (CFA)-induced edema and hypersensitivity in the rat. Curr Protoc Pharmacol. 2015;70(1). doi:10.1002/0471141755. ph0504s70

25. Yoon S-Y, Patel D, Dougherty PM. Minocycline blocks lipopolysaccharide induced hyperalgesia by suppression of microglia but not astrocytes. Neuroscience. 2012;221:214-224. doi:10.1016/j neuroscience.2012.06.024

26. Yu G-M, Liu D, Yuan N, Liu B-H. Dual role of acid-sensing ion channels 3 in rheumatoid arthritis: destruction or protection? Immunopharmacol Immunotoxicol. 2018;40(4):273-277. doi:10.108 0/08923973.2018.1485156

27. Townsend EA, Naylor JE, Negus SS, et al. Effects of nalfurafine on the reinforcing, thermal antinociceptive, and respiratory-depressant effects of oxycodone: modeling an abuse-deterrent opioid analgesic in rats. Psychopharmacology. 2017;234(17):2597-2605. doi:10.1007/ s00213-017-4652-3

28. Abbas M, Alzarea S, Papke RL, Rahman S. The $\alpha 7$ nicotinic acetylcholine receptor positive allosteric modulator prevents lipopolysaccharide-induced allodynia, hyperalgesia and TNF-alpha in the hippocampus in mice. Pharmacol Rep. 2019;71(6):1168-1176. doi:10.1016/j.pharep.2019.07.001

29. Chaplan SR, Bach F, Pogrel J, Chung J, Yaksh T. Quantitative assessment of tactile allodynia in the rat paw. $J$ Neurosci Methods. 1994;53(1):55-63. doi:10.1016/0165-0270(94)90144-9

30. Tumati S, Largent-Milnes TM, Keresztes A, et al. Repeated morphine treatment-mediated hyperalgesia, allodynia and spinal glial activation are blocked by co-administration of a selective cannabinoid receptor type-2 agonist. J Neuroimmunol. 2012;244(1-2):23-31. doi:10.1016/ j.jneuroim.2011.12.021

31. Xie JY, Herman DS, Stiller C-O, et al. Cholecystokinin in the rostral ventromedial medulla mediates opioid-induced hyperalgesia and antinociceptive tolerance. $J$ Neurosci. 2005;25(2):409-416. doi:10.1523/ JNEUROSCI.4054-04.2005

32. Do Amaral JF, Silva MIG, de Aquino Neto MRA. Antinociceptive effect of the monoterpene R-(+)-limonene in mice. Biol Pharm Bull. 2007;30(7):1217-1220. doi:10.1248/bpb.30.1217

33. Tumati S, Roeske WR, Vanderah TW, Varga EV. Sustained morphine treatment augments prostaglandin E2-evoked calcitonin gene-related peptide release from primary sensory neurons in a PKA-dependent manner. Eur J Pharmacol. 2010;648(1-3):95-101. doi:10.1016/j. ejphar.2010.08.042

34. Eruygur N, Koçyiğit U, Taslimi P, Ataș M, Tekin M, Gülçin I. Screening the in vitro antioxidant, antimicrobial, anticholinesterase, antidiabetic activities of endemic Achillea cucullata (Asteraceae) ethanol extract. S Afr J Bot. 2019;120:141-145. doi:10.1016/j. sajb.2018.04.001

35. Mathew S, Abraham TE. In vitro antioxidant activity and scavenging effects of Cinnamomum verum leaf extract assayed by differen methodologies. Food Chem Toxicol. 2006;44(2):198-206. doi:10.1016/j.fct.2005.06.013

36. Chinedu E, Arome D, Ameh FS. A new method for determining acute toxicity in animal models. Toxicol Int. 2013;20(3):224 doi:10.4103/0971-6580.121674

37. Idris Z, Abbas M, Nadeem $H$. The benzimidazole derivatives, B1 $(\mathrm{N}$ [(1H-benzimidazol-2-yl) methyl]-4-methoxyaniline) and B8 $(\mathrm{N}-\{4-$ [(1H-benzimidazol-2-yl) methoxy] phenyl $\}$ acetamide) attenuate morphine-induced paradoxical pain in mice. Front Neurosci. 2019;13::101. doi:10.3389/fnins.2019.00101

38. Roy S, Ukil B, Lyndem L, El-Nezami H. Acute and sub-acute toxicity studies on the effect of Senna alata in Swiss Albino mice. Cogent Biol. 2016;2(1):1272166. doi:10.1080/23312025.20 16.1272166

39. Ukpo GE, Ebuehi O, Kareem A. Evaluation of moxifloxacin-induced biochemical changes in mice. Indian J Pharm Sci. 2012;74(5):454. doi:10.4103/0250-474X.108422
40. Ji -R-R, Strichartz G. Cell signaling and the genesis of neuropathic pain. Sci STKE. 2004;2004(252):re14-re14.

41. Randić M. Modulation of long-term potentiation of excitatory synaptic transmission in the spinal cord dorsal horn. Synaptic Plast Pain. 2009;219-254.

42. McMahon SB, Malcangio M. Current challenges in glia-pain biology. Neuron. 2009;64(1):46-54. doi:10.1016/j.neuron.2009.09.033

43. Miranda HF, Sierralta F, Aranda N, et al. Antinociception induced by rosuvastatin in murine neuropathic pain. Pharmacol Rep. 2018;70 (3):503-508. doi:10.1016/j.pharep.2017.11.012

44. DeLeo JA, Yezierski RP. The role of neuroinflammation and neuroimmune activation in persistent pain. Pain. 2001;90(1):1-6. doi:10.1016/S0304-3959(00)00490-5

45. Gardell LR, Wang R, Burgess SE, et al. Sustained morphine exposure induces a spinal dynorphin-dependent enhancement of excitatory transmitter release from primary afferent fibers. $J$ Neurosci. 2002;22 (15):6747-6755. doi:10.1523/JNEUROSCI.22-15-06747.2002

46. Ward JE, Tan X. Peroxisome proliferator activated receptor ligands as regulators of airway inflammation and remodelling in chronic lung disease. PPAR Res. 2007;2007:1-12. doi:10.1155/2007/14983

47. Devchand PR, Keller H, Peters JM, Vazquez M, Gonzalez FJ, Wahli W. The PPAR $\alpha$-leukotriene B4 pathway to inflammation control. Nature. 1996;384(6604):39. doi:10.1038/384039a0

48. Ricote M, Li AC, Willson TM, Kelly CJ, Glass CK. The peroxisome proliferator-activated receptor- $\gamma$ is a negative regulator of macrophage activation. Nature. 1998;391(6662):79. doi:10.1038/34178

49. LoVerme J, Russo R, La Rana G, et al. Rapid broad-spectrum analgesia through activation of peroxisome proliferator-activated receptor- $\alpha . J$ Pharmacol Exp Ther. 2006;319(3):1051-1061. doi:10.1124/jpet.106.111385

50. Taylor BK, Dadia N, Yang CB, Krishnan S, Badr M. Peroxisome proliferator-activated receptor agonists inhibit inflammatory edema and hyperalgesia. Inflammation. 2002;26(3):121-127. doi:10.1023/ A:1015500531113

51. Morgenweck J, Abdel-Aleem O, McNamara K, Donahue R, Badr M, Taylor B. Activation of peroxisome proliferator-activated receptor $\gamma$ in brain inhibits inflammatory pain, dorsal horn expression of Fos, and local edema. Neuropharmacology. 2010;58(2):337-345. doi:10.1016/j.neuropharm.2009.10.008

52. Bernardo A, Minghetti L. Regulation of glial cell functions by PPAR. J Neurosci Methods. 2008;2008.

53. Griggs RB, Donahue RR, Morgenweck J, et al. Pioglitazone rapidly reduces neuropathic pain through astrocyte and non-genomic PPAR $\gamma$ mechanisms. Pain. 2015;156(3):469. doi:10.1097/01.j.pain.00004 60333.79127.be

54. Jia H-B, Wang X-M, Qiu L-L. Spinal neuroimmune activation inhibited by repeated administration of pioglitazone in rats after L5 spinal nerve transection. Neurosci Lett. 2013;543:130-135. doi:10.1016/j. neulet.2013.03.046

55. Moreno S, Farioli-Vecchioli S, Ceru M. Immunolocalization of peroxisome proliferator-activated receptors and retinoid $\mathrm{X}$ receptors in the adult rat CNS. Neuroscience. 2004;123(1):131-145. doi:10.1016/ j.neuroscience.2003.08.064

56. Flohé L, Brigelius-Flohé R, Saliou C, Traber MG, Packer L. Redox regulation of NF-kappa B activation. Free Radic Biol Med. 1997;22 (6):1115-1126. doi:10.1016/S0891-5849(96)00501-1

57. Popa-Wagner A, Mitran S, Sivanesan S, Chang E, Buga A-M. RO. S and brain diseases: the good, the bad, and the ugly. Oxid Med Cell Longev. 2013;2013:1-14. doi:10.1155/2013/963520

58. Rodrigues FS, Souza MA, Magni DV, et al. N-acetylcysteine prevents spatial memory impairment induced by chronic early postnatal glutaric acid and lipopolysaccharide in rat pups. PLoS One. 2013;8(10): e78332. doi:10.1371/journal.pone.0078332

59. Rosales-Corral S, Reiter RJ, Tan D-X, Ortiz GG, Lopez-Armas G. Functional aspects of redox control during neuroinflammation. Antioxid Redox Signal. 2010;13(2):193-247. doi:10.1089/ ars.2009.2629 
60. Karamese SA, Toktay E, Unal D, Selli J, Karamese M, Malkoc I. The protective effects of beta-carotene against ischemia/reperfusion injury in rat ovarian tissue. Acta Histochem. 2015;117(8):790-797. doi:10.1016/j.acthis.2015.07.006

61. Hsieh C-T, Lee Y-J, Lee JW, et al. Interleukin-1 receptor antagonist ameliorates the pain hypersensitivity, spinal inflammation and oxidative stress induced by systemic lipopolysaccharide in neonatal rats. Neurochem Int. 2020;135:104686. doi:10.1016/j.neuint.2020.104686

62. Keeble JE, Bodkin JV, Liang L, et al. Hydrogen peroxide is a novel mediator of inflammatory hyperalgesia, acting via transient receptor potential vanilloid 1-dependent and independent mechanisms. Pain. 2009;141(1-2):135-142. doi:10.1016/j.pain.2008.10.025
63. Ndengele MM, Cuzzocrea S, Esposito E, et al. Cyclooxygenases 1 and 2 contribute to peroxynitrite-mediated inflammatory pain hypersensitivity. FASEB J. 2008;22(9):3154-3164. doi:10.1096/fj.08108159

64. Wang Z-Q, Porreca F, Cuzzocrea S, et al. A newly identified role for superoxide in inflammatory pain. $J$ Pharmacol Exp Ther. 2004;309 (3):869-878. doi:10.1124/jpet.103.064154

65. Alemán-González-Duhart D, Tamay-Cach F, Correa-Basurto J, Padilla-Martínez II, Álvarez-Almazán S, Mendieta-Wejebe JE. In silico design, chemical synthesis and toxicological evaluation of 1 , 3-thiazolidine-2, 4-dione derivatives as PPAR $\gamma$ agonists. Regul Toxicol Pharmacol. 2017;86:25-32. doi:10.1016/j.yrtph.2017.02.008

\section{Publish your work in this journal}

Drug Design, Development and Therapy is an international, peerreviewed open-access journal that spans the spectrum of drug design and development through to clinical applications. Clinical outcomes, patient safety, and programs for the development and effective, safe, and sustained use of medicines are a feature of the journal, which has also been accepted for indexing on PubMed Central. The manuscript management system is completely online and includes a very quick and fair peer-review system, which is all easy to use. Visit http://www. dovepress.com/testimonials.php to read real quotes from published authors. 